\title{
Characterisation of fluid flow conditions and paths in the Buntsandstein Gp. sandstones reservoirs, Upper Rhine Graben
}

\author{
Claire Bossennec ${ }^{1, *}$ (D), Yves Géraud ${ }^{2}$ (D), Johannes Böcker ${ }^{3}$, Bernd Klug ${ }^{3}$, Luca Mattioni ${ }^{4}$, \\ Lionel Bertrand ${ }^{5}$ and Isabelle Moretti ${ }^{6,7}$ \\ ${ }^{1}$ GeoRessources, Université de Lorraine, Nancy 54000, France, now at Geothermal Science and Technology, Technical University of \\ Darmstadt, Darmstadt 64287, Germany \\ ${ }^{2}$ GeoRessources, Université de Lorraine, Nancy 54000, France \\ 3 Neptune Energy, Lingen 49808, Germany \\ ${ }^{4}$ IFPEN, Rueil-Malmaison, France \\ 5 Enerex, Vandoeuvre-lès-Nancy 54500, France \\ ${ }^{6}$ ENGIE, Courbevoie 92400, France, now at E2S, UPPA, Pau 64012, France \\ ${ }^{7}$ IsTEP, UPMC, Paris 75005, France
}

Received: 18 June 2020 / Accepted: 13 July 2021 / Publishing online: 5 August 2021

\begin{abstract}
Deeply buried sandstone reservoirs are targeted in the Upper Rhine Graben (URG) for geothermal and hydrocarbon resources. These reservoirs are affected by a convective heat flow along fault zones and have a complex diagenetic and deformation history recorded in their paragenetic sequence. Here, the focus is made on siderite and barite cementation characterisation, which trace paleo geothermal circulations within the fracture network affecting the Buntsandstein $\mathrm{Gp}$. sandstones. A double approach on geochemistry and fracture network features is used to characterise fluid-flow episodes in the rift basin and on its shoulders. Barite sulphur isotopic signature suggests a common source for all the locations. However, Rare Earth Elements distribution patterns, oxygen isotopic ratios, and fluid inclusion study suggest two distinct flow regimes for fluids associated with barite precipitation along the shoulders and at depth in the middle of the graben. The barite has a higher content in total REE and contains non-saline fluid inclusions on the graben shoulders, suggesting that fluid circulations within the border faults interact with sulphate rich layers and precipitate at temperature above $150^{\circ} \mathrm{C}$. In deepseated samples from the central part of the basin, barite fluid inclusions show a wide range of salinities, suggesting a higher contribution of sedimentary brines and precipitation at lower temperatures $\left(<150^{\circ} \mathrm{C}\right)$. According to their REE signature, these barite mineralisations are associated with siderite and apatite with a diagenetic source. A conceptual model for fluid circulation within the basin is built from this new dataset. Fast and deep down- and up-flows occur along the major border faults, locally leaching evaporitic horizons. A part of the infiltrated meteoric waters reaches the centre of the basin, where it then mixes with the brines in sedimentary. This new characterisation of fluid pathways in the targeted reservoir brings insights into geothermal circulation compartmentalisation at the basin scale.
\end{abstract}

Keywords: geothermal system / geochemistry / fracture mineralisation / fluid pathways / Upper Rhine Graben / Buntsandstein Gp.

Résumé - Caractérisation des conditions et des chemins de circulations de fluides dans les réservoirs gréseux du Buntsandstein Gp., Graben du Rhin supérieur. Les réservoirs gréseux profonds du Graben du Rhin supérieur(URG) sont des cibles pour l'exploration et l'exploitation des ressources géothermiques et d'hydrocarbures. Ces réservoirs, affectés par des transferts convectifs de chaleur le long des zones de faille, ont une histoire diagénétique et de déformation complexe, enregistrée par la séquence paragénétique des fractures. Dans cette étude, l'accent est mis sur la caractérisation des cimentations de sidérite et de barytine qui retracent des paléo-circulations géothermiques au sein du réseau de fractures affectant les grès du Buntsandstein Gp. Ces minéralisations sont étudiées avec une double approche

\footnotetext{
*Corresponding author: bossennec.claire@gmail.com;

claire.bossennec@tu-darmstadt.de
} 
géochimique et structurale (failles et réseaux de fractures associés), afin de caractériser les épisodes d'écoulement de fluides pour différents éléments structuraux dans la partie centrale du fossé et sur ses épaules Une source commune est suggérée pour le soufre par la signature isotopique de la barytine, et e qu'importe la provenance des échantillons. La répartition des terres rares, les rapports isotopiques de l'oxygène et l'étude des inclusions fluides suggèrent cependant deux régimes d'écoulement des fluides minéralisateurs de la barytine. Sur les épaules du fossé, la barytine a une teneur plus élevée en terres rares et contient des inclusions de fluides non salins. Ceci suggère que les fluides au niveau des failles de la bordure du Graben interagissent avec les couches riches en sulfate et précipitent à des températures élevées $\left(>150^{\circ} \mathrm{C}\right)$. Dans les réservoirs gréseux profonds, situés dans la partie centrale du fossé, les inclusions fluides dans les barytines présentent une large gamme de salinités et des températures plus basses de piégeage $\left(<150^{\circ} \mathrm{C}\right)$, ce qui suggère une contribution plus importante des saumures sédimentaires. Ces minéralisations de barytine sont associées à des sidérites et à de l'apatite d'origine diagénétique, selon leur signature en terres rares. Ces données sont utilisées pour construire un modèle conceptuel de circulation des fluides dans le Graben, selon lequel l'eau météorique s'infiltre rapidement le long des failles bordières, jusqu'à la base du bassin, avec un lessivage local des horizons évaporitiques, puis une précipitation à partir de ces fluides géothermiques qui remontent durant l'activité de la faille. Une partie de ces fluides météoriques atteint le centre du bassin, où ces fluides ascendants se mélangent aux saumures sédimentaires. Cette nouvelle caractérisation des remplissages de fractures au sein de ce réservoir sédimentaire apporte des perspectives sur la compréhension de la compartimentation des circulations géothermales à l'échelle du bassin.

Mots clés : système géothermique / géochimie / minéralisation des fractures / chemins de circulation des fluides / Graben du Rhin / Buntsandstein Gp.

\section{Introduction}

Fluids are involved in widespread deformation processes in many geological contexts such as rift basins, foreland basins and oceanic ridges. Their origins are multiple: basement derived, connate or meteoric, and they are commonly mixtures between these sources (Person and Garven, 1992; Pribnow and Schellschmidt, 2000; Lampe et al., 2001; Bouch et al., 2006; Staude et al., 2009; Pfaff et al., 2010; Bons et al., 2014). For rift systems, the enhanced thermal regime at the rift initiation stage provides a high heat flow caused by lithospheric thinning (Ranalli and Rybach, 2005; Cloetingh et al., 2010). This thermal regime can be recorded in mineralisation in fault and fractures planes and in the matrix of sedimentary formations (Gleeson et al., 2001; Wilkinson, 2003; McKinley et al., 2011; Olivarius et al., 2015; Kristensen et al., 2016). The tracking of the origin of fluids is crucial to understand the processes that affect the hydraulic properties of the sedimentary formations and their evolution in space and time. These aspects have to be integrated into characterisation studies for mineral and nonmineral (hydrocarbon, water) resource exploration and production (Bense et al., 2013; Griffiths et al., 2016; Vidal and Genter, 2018). Such processes are proposed as significant for the development of Mississippi Valley Type ore-deposits (Paradis et al., 2007; Pfaff et al., 2010; Boiron et al., 2011). For geothermal energy purposes, the characterisation of the fluid origin, temperature, and migration pathways, is essential to estimate resources. For petroleum systems analysis, reservoir compartmentalisation can affect field productivity due to sedimentary features and fault zones architecture, including vein occurrence.

The fluid origin of the mineralisation hosted in rift basins is complex because of the diversity of fluid sources and fluid transfer conditions. Thus, it requires a double approach on geochemical and structural characterisation from the fault system scale to the micro-fracture scale. This study aims to characterise the origin and conditions of fracture mineralisation within the Buntsandstein Gp. sandstones within the Upper Rhine Graben (URG). These Permo-Triassic sandstones are a target for hydrocarbon and geothermal energy exploration and production. These sandstones are the first reservoirs at the bottom of the pre-rift sedimentary deposits (Böcker et al., 2016). They cover up the basement in several already well-studied locations (e.g. Soultz, Rittershoffen) (Vidal et al., 2015; Griffiths et al., 2016; Kushnir et al., 2018; Vidal and Genter, 2018). These sandstones outcrop on both shoulders of the graben; in the Vosges and Pfalz areas in the West, and the Schwarzwald and Odenwald Massifs in the East. Several studies have already discussed paleo- and current fluid-flows schema through faults in the area (Staude et al., 2009; Bons et al., 2014; Walter et al., 2016, 2018, 2019). Active thermal sources on the graben's shoulders also indicate that fluid flow and mineralisation are still ongoing (Baatartsogt et al., 2007; Loges et al., 2012). However, these studies proposed mineralisation schemes in the basement and the Schwarzwald area's sedimentary cover, which have a different Cenozoic evolution than the areas sampled here. These mineralising events were not explored within deep-seated sandstone reservoirs, which though are targets for geothermal energy production. This study brings new insights into the fluid types responsible for the fracture network cementation in the area to derisk reservoir operations.

The data collected here relate to barite, carbonate, and apatite precipitation in the pre, syn and post-rift phases of the basin. The elements obtained make it possible to discuss the source of the precipitated products, the nature of the fluids that permitted the transport of this material and the temperature conditions of precipitation.

By integrating previous works and new geochemical analysis in a structural context, the nature of the source(s) and the understanding of fluid flow regimes in the Buntsandstein Gp. sandstones is improved. After defining the geological context, focusing on the current knowledge of the fluid flow episodes affecting the Buntsandstein Gp., the sampled 
structural settings and the mineralisations geochemical signature will be presented.

The nature and fluid precipitation temperature in the fracture and fault vicinity and the basin-scale variability of the mineralisations will be subsequently compared to previous studies outcomings to elaborate a renewed model of flow pathways in the URG.

\section{Fluid flow in fault zones in the Upper Rhine Graben}

The Upper Rhine Graben is a segment of the European Cenozoic Rift System (ECRIS). It is a typical example of intracontinental rifting. It is bordered northward by the Hunsrück-Taunus Massif, and southward by the Jura (Fig. 1). This NNE striking graben is $300 \mathrm{~km}$ long, with a width of 30 to 40 km (Ziegler, 1992; Sissingh, 1998; Derer et al., 2005). The Vosges Mountains border the basin on the West, and on the East, the Odenwald and Schwarzwald Massifs. The entire area has a complex geological history involving several tectonic activity phases, resulting in fluid flows of different nature and origin (Fig. 2).

\subsection{Structural settings}

Several sets of faults and fractures networks affect the area, with a first-order compartmentalisation with NNE-SSW oriented faults, and a secondary network of fault and fracture striking $\mathrm{N} 000^{\circ} \mathrm{E}, \mathrm{N} 040^{\circ} \mathrm{E}, \mathrm{N} 120^{\circ} \mathrm{E}$ and $\mathrm{N} 150-\mathrm{N} 170^{\circ} \mathrm{E}$, (Illies, 1972; Schumacher, 2002; Lopes Cardozo and Behrmann, 2006) (Fig. 1). In addition, the sub-basins segmenting the URG are controlled by pre-existing Variscan lineaments (Bertrand et al., 2018) affecting the basement (Edel et al., 2007; Skrzypek, 2011).

During Permian, the geodynamical context switched from relaxation and collapse of the Variscan Belt to an extensive intra-plate endorheic basin, with an intense tectonic activity (Schumacher, 2002; Ziegler, 2005). A series of basins developed, compartmentalised by reactivated NW-SE and NE-SW striking faults inherited from Variscan orogeny. The Buntsandstein Gp. sandstones were deposited in a high to moderate sinuosity fluvial system under semi-arid to arid conditions (Bourquin et al., 2006, 2009). These sandstones are overburden by Middle and Upper Triassic carbonate evaporitic deposits, characterising marine transgression and carbonateevaporitic deposits. The thermal subsidence regime started in Triassic and continued up to Late Jurassic. A phase of uplift and erosion affected the area from Late Jurassic-Early Cretaceous up to Early Eocene. This erosion event resulted in a SE dipping of Mesozoic formations. The uplift centre was located NW-NNW of the current URG. This uplift phase was associated with volcanic activity in the Rhenish Massif (Lutz et al., 2010, 2013). The rift initiation started in the Eocene in response to the Alpine N-S compression and led to the deposit of the detrital Eocene Basal Formation. During Oligocene, the subsidence began to increase regionally. Marine ingressions flooded the whole basin, from the North Sea and the Alpine Sea (Roussé, 2006). These ingressions resulted in the deposition of clayey organic-rich carbonates, sandstones, and marls even across the graben margins.
Due to a change of the regional stress regime to a transtensive sinistral shear, and the initiation of NE-SW striking mini-basins in the late Oligocene and Miocene, the depocenters shifted to the northern part of the URG. The southern segment of the URG underwent a gradual uplift at this period, beginning in the Burdigalian (17 Ma). This uplift probably reactivated NE to ENE striking faults (Rotstein et al., 2005).

The current geometry of the URG settled during the middle Miocene uplift. Simultaneously, the northern part of the URG (north of Soultz-sous-Forêts) underwent a third phase of subsidence from Pliocene to Quaternary (Sissingh, 1998; Schumacher, 2002; Cloetingh et al., 2005, 2006; Bourgeois et al., 2007).

During this burial and uplift history, the Buntsandstein Gp. sandstones were affected by a series of tectonic deformation events accompanied by fault-related fluid circulations (Clauer et al., 2008; Blaise et al., 2016; Walter et al., 2018).

\subsection{Fluid flows phases and geothermal activity}

In the URG, the heat flow is relatively high (up to $150 \mathrm{~mW} / \mathrm{m}^{2}$ ) (Lucazeau and Vasseur, 1989; Baillieux et al., 2013; Harlé et al., 2019). Local thermal anomalies are marked by temperatures exceeding $150{ }^{\circ} \mathrm{C}$ at $2000 \mathrm{~m}$ depth (Pribnow and Schellschmidt, 2000; Baillieux et al., 2013; Guillou-Frottier et al., 2013). These thermal anomalies affect the Buntsandstein $\mathrm{Gp}$. sandstone reservoirs and are of crucial importance for geothermal resource operations. Their restricted spatial locations suggest that the URG temperature distribution is not homogeneous (Vidal, 2017). The isotherms established from well temperature measurements show positive anomalies that are often concentric and centered on the fault alignment, particularly at Soultz and Rittershoffen. The processes proposed to explain these anomalies and their structures are fluid flows at the basement-sediment interface (Dubois et al., 1996; Bächler et al., 2003; Baillieux et al., 2013; Guillou-Frottier et al., 2013). The geochemistry of brines and formation water also gives an idea of the first order of fluid flow regimes at the basement-sediment interface (Sanjuan et al., 2016). Thus, it appears that current fluid flows are structured at the basin and local scale.

At the basin scale, along E-W sections, the meteoric water infiltrates from the reliefs of both shoulders of the rift.

In the direction N-S to NNW-SSE, the NE-SW oriented faults and the sedimentary layers, which act as cover; control the first-order fluid flows (Meixner et al., 2018). Salinity data collected on fluids from the geothermal sites between Soultz and Landau suggest that they correspond to primary brines from water supersaturated in evaporites mixed with meteoric waters with very low salinity (Buntsandstein deep aquifer) (Sanjuan et al., 2010, 2016; Walter et al., 2018). The brines resulting from the dissolution of halite following the various transgression-regression cycles from Triassic to Oligocene are also a part of the fluid mixture (Sanjuan et al., 2016; Walter et al., 2016, 2018). Given the variations in geochemical properties of these current brines, several reservoirs are candidates (Walter et al., 2018), each with a specific type of fluids: crystalline basement aquifer, Buntsandstein aquifers, Muschelkalk aquifers, clay sequences, marls and evaporite 

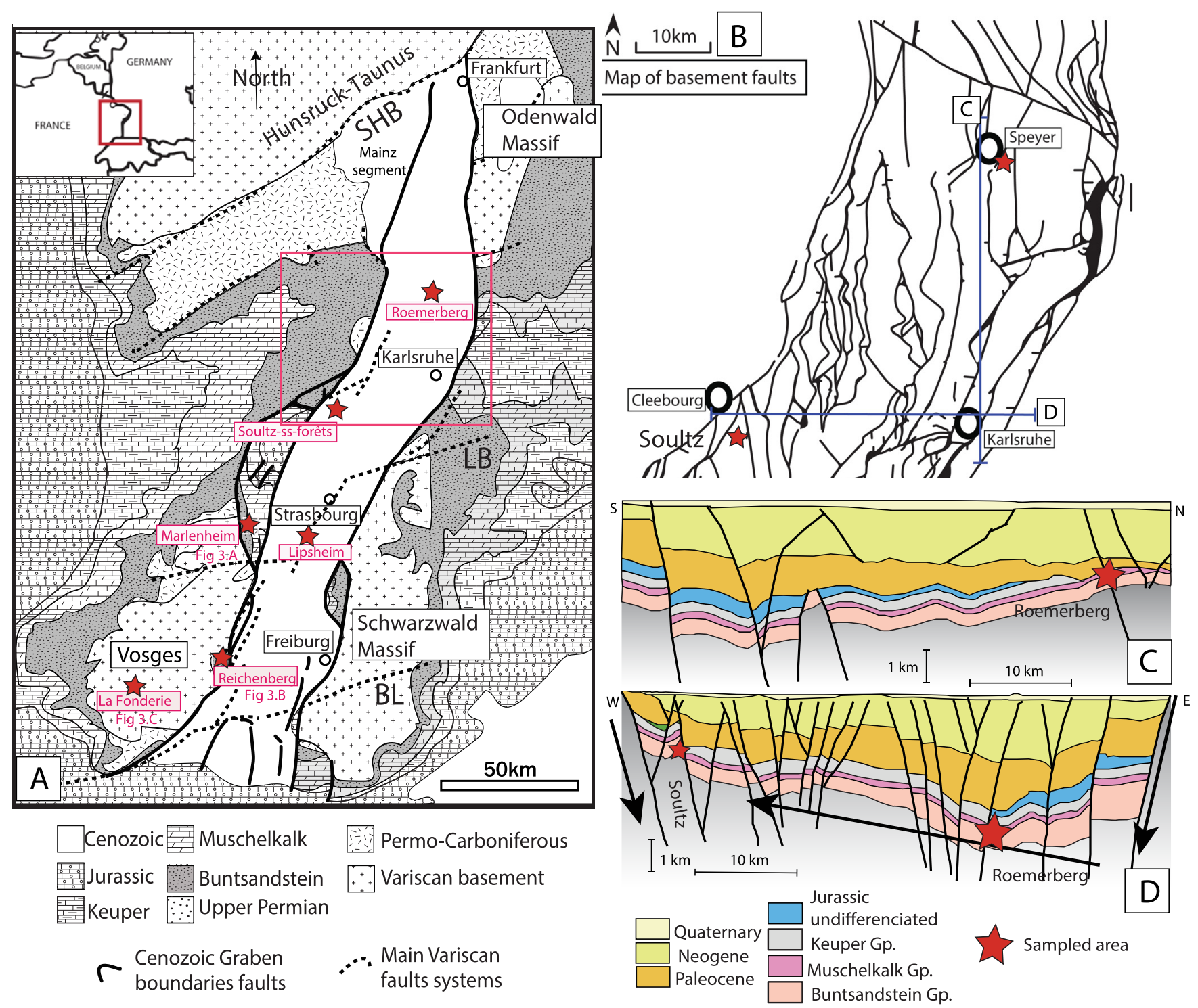

Fig. 1. Geological context of the study. (A) Simplified geological map of the Upper Rhine Graben area, after Eisbacher and Fielitz (2010) and Bossennec et al. (2018), with locations of sampled areas represented by red stars. The position of B windows is indicated in the pink rectangle. Major Variscan and Cenozoic faults are placed according to (Schumacher, 2002). BL: Badenweiler-Lenzkirch fault system; LB: Lalaye-LubineBaden-Baden fault system; SHB: South Hunsrück Taunus border fault system. (B) Map of the basement fault pattern in the area of Cleebourg, Karlsruhe, Speyer. (C, D) Schematic cross-sections located on Figure 1B, with indications of the current hypothesis on waters pathway infiltration and migration in the URG (Sanjuan et al., 2010; Sanjuan et al., 2016; Böcker et al., 2016; Vidal and Genter, 2018).

levels of the Keuper, Jurassic limestone aquifers. Depending on the studies, these aquifers are not described with the same details. Some authors group the Middle Triassic and Upper Triassic under the name Triassic aquifer. Moreover, locally, tertiary aquifer influence is marked by sulphate isotopic signature (Staude et al., 2011; Loges et al., 2012).

The different temperature gradients and the results of geochemical studies of the geothermal fluids suggest the scheme illustrated on Figure 1. Convection loops might be present at the basement-sedimentary cover interface with recharge points on the graben shoulders, and upward migrations of sedimentary brine to horst structures (e.g. Soultz horst). The upward migrations of sedimentary brine might be consistant with thermal anomalies spotted along the URG (Soultz, Rittershoffen, Landau). The same drains control geothermal and hydrocarbon fluids migrations. These fluids' deep circulations would be spatially limited to an area between Cronenbourg and Eschau for the southern boundary and Riedstadt-Groß-Gerau for the northern border. As it is located in this area, the Roemerberg oil-field (see location Fig. 1) is under the influence of these deep hot brines (Böcker et al., 2016).

The main reservoir for the hot brine feeding the geothermal sites would be situated in the eastern part of the graben, where temperatures reach $225^{\circ} \mathrm{C}$, and more than $4 \mathrm{~km}$ depth for the 


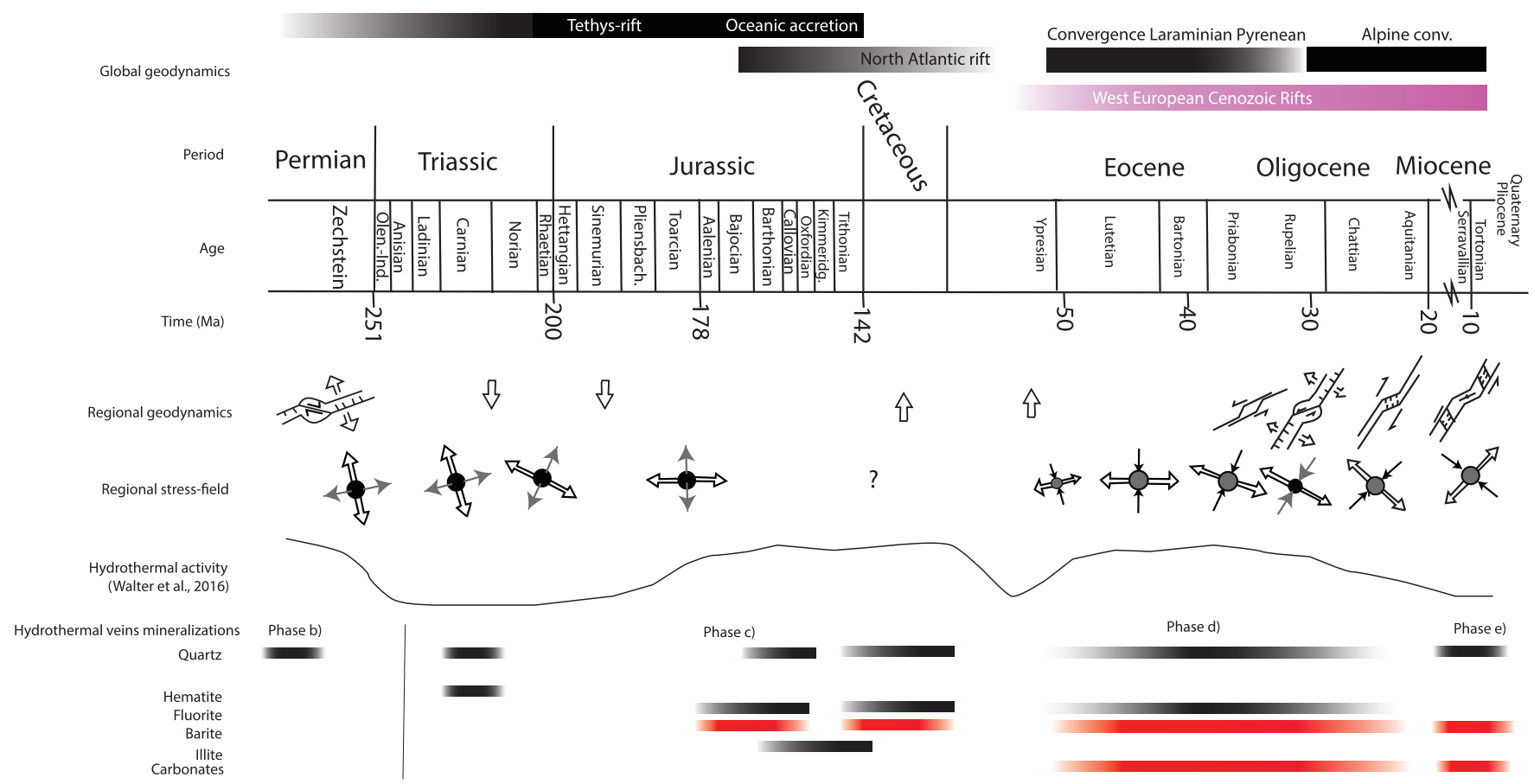

Fig. 2. Summary of the mineralisation phases relative to the regional structural context and geodynamic events, with the positioning of the mineralisations studied here in red. The hydrothermal activity represents here qualitatively the intensity of hydrothermal pulses recorded within fractures infills regionally. The paragenesis related to these hydrothermal circulations is detailed.

Buntsandstein Gp. (Sanjuan et al., 2010, 2013; Dezayes et al., 2015). These hot brines would then migrate from the graben centre to the northwestern edge, infiltrate the granitic basement, and rise upwards to the basement-sediment interface at the Soultz and Landau geothermal sites (Sanjuan et al., 2016). At the block (field) scale, local upwelling of the isotherms indicates local circulation systems, along some of the NE-SW orientation faults (Sanjuan et al., 2016). Many of the geochemical data from this study suggest a contribution of Cenozoic fluids and recent meteoric waters in Mesozoic and granitic basement aquifers. The potential connection between these two scales remains unknown due to the significant uncertainties about these fluid flow pathways and timing. For current fluid flow, a convection system, still active today in the URG basin, is also assessed by previous works (Sanjuan et al., 2010; Vidal et al., 2015; Freymark et al., 2017; Vidal and Genter, 2018).

A question remains regarding the evolution of these fluid circulation systems before the rifting, during the rift opening, and at the present time.

For the URG area, six major stages were reported (Fig. 2 and Tab. 1) (Staude et al., 2009, 2011; Loges et al., 2012; Walter et al., 2016, 2017, 2019; Burisch et al., 2017b; Dezayes and Lerouge, 2019):

a. Carboniferous stage: According to fluid inclusions in hydrothermal mineralisation and stable isotope data, Variscan fluids are generally of low salinity. Homogenisation temperatures range from 150 to $350^{\circ} \mathrm{C}$. There is no evidence that the Variscan fluid system was open to the surface, so after correction from lithostatic pressure, trapping temperatures reached $250-350{ }^{\circ} \mathrm{C}$. Such conditions have been documented for similar veins along the Variscan Belt (Cathelineau et al., 2004; Schwinn et al., 2006; Boiron et al., 2011).

b. Permian stage: Permian fractures are filled by quartz, $\mathrm{Sb}-$ $\mathrm{Ag}$, minor barite and fluorite assemblage and present aqueous fluid inclusions of two types, with varying salinities (Baatartsogt et al., 2007). Most fluid inclusions in these veins show low salinities $(<10 \mathrm{wt} . \%)$. Homogenisation temperatures range from 150 to $350{ }^{\circ} \mathrm{C}$. The second minor group of inclusions shows calculated salinities ranging between 23.6 and $27.2 \mathrm{wt} . \%$. Homogenisation temperatures range from 90 to $150^{\circ} \mathrm{C}$.

c. Jurassic-Early Cretaceous stage: The URG area records several Late Jurassic high-temperature hydrothermal events all over Western Europe. These events are linked to far-field stress changes related to Tethys and Atlantic rifting (Guillocheau et al., 2000; Ziegler et al., 2004; Staude et al., 2009; Brockamp et al., 2011; Cathelineau et al., 2012). These events are a possible explanation for local illitisation of Rotliegend and Buntsandstein sandstones (illitisation dated from 157 to $137 \mathrm{Ma}$ ) in the southern Schwarzwald and the Vosges Massifs (Brockamp and Clauer, 2005; Clauer et al., 2008; Brockamp et al., 2011). Barite-quartz-sulfide assemblages, dated from 150 to $110 \mathrm{Ma}$, also record these hydrothermal events overlapping the illitisation period partly (Schwinn et al., 2006; Danišík et al., 2010). The commonly presented genetic model consists in a deep down-flow of basin brines within the Variscan basement from Triassic to Jurassic times, where fluids reached equilibrium with the basement (Stober and Bucher, 2004; Baatartsogt et al., 2007; Staude et al., 2011; Bons and Gomez-Rivas, 2013; Bons et al., 


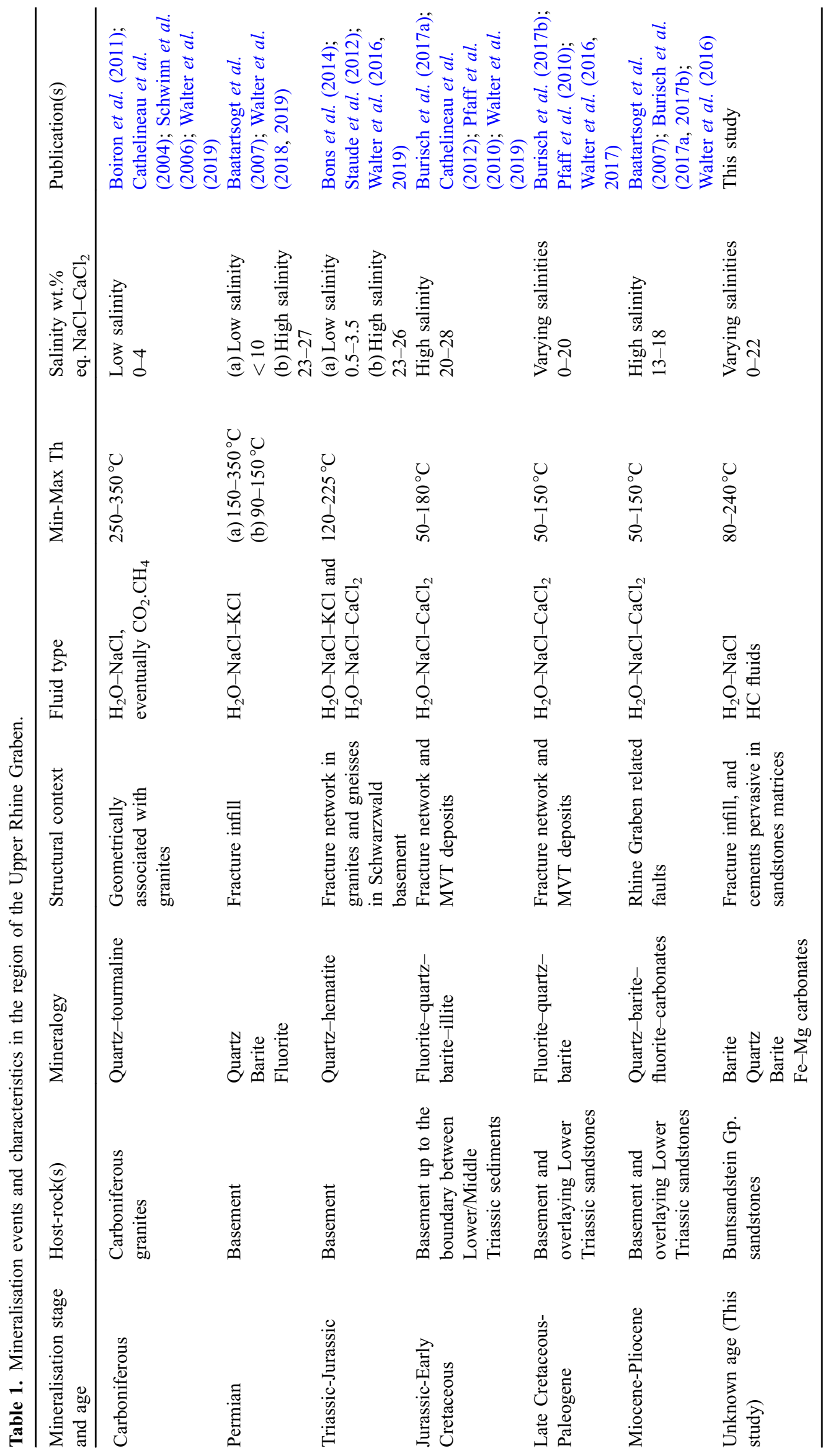



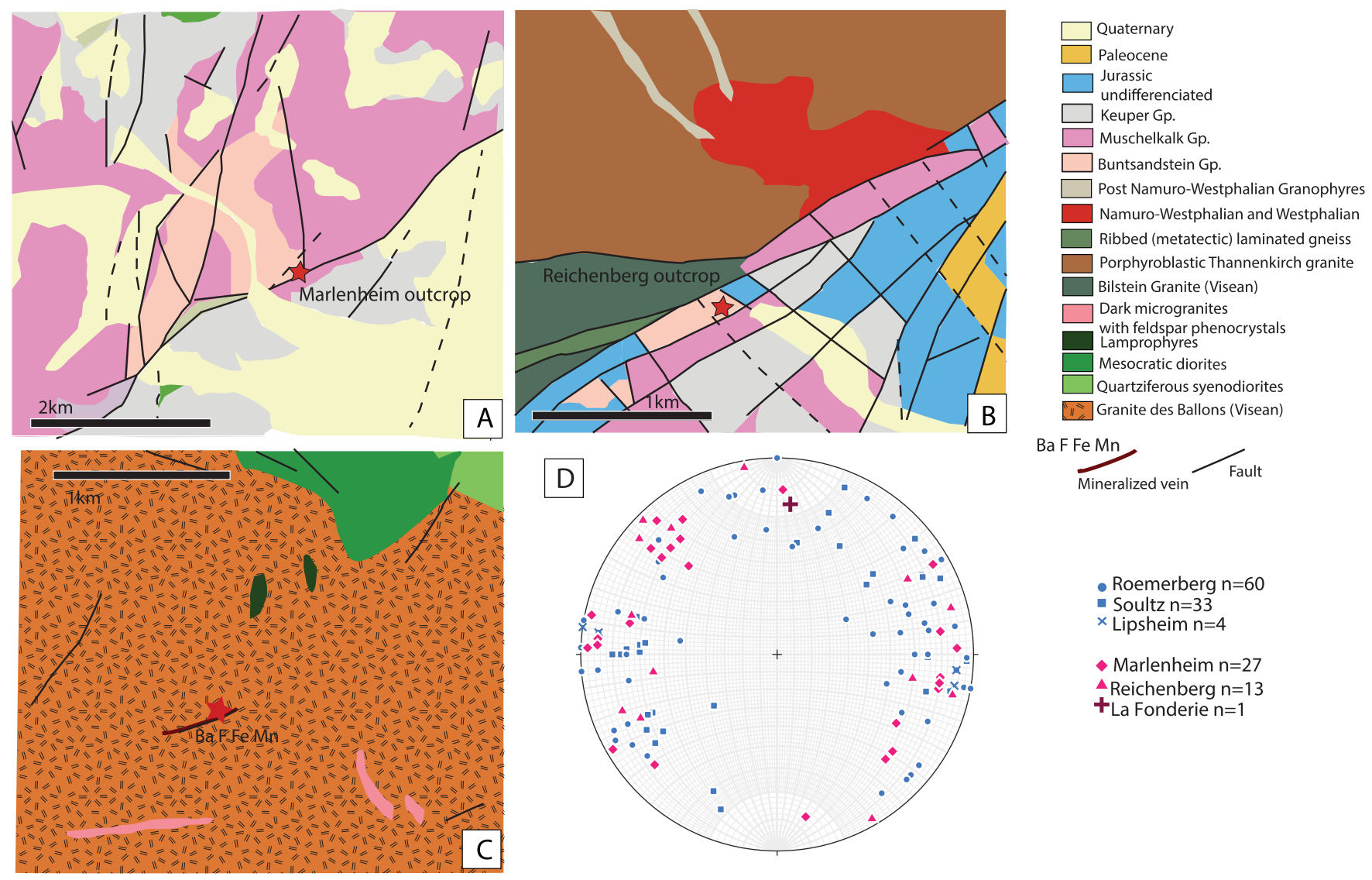

$$
\begin{aligned}
& \text { - Roemerberg } n=60 \\
& \text { Soultz } n=33 \\
& \times \text { Lipsheim } n=4 \\
& \text { Marlenheim } n=27 \\
& \text { Reichenberg } n=13 \\
& \text { +La Fonderie } n=1
\end{aligned}
$$

Fig. 3. Local structural context of samples. Red stars symbolise the outcrop position. (A) Structural scheme of Marlenheim outcrop. (B) Structural scheme of Reichenberg outcrop. (C) Structural scheme of La Fonderie outcrop. (D) Upper hemisphere stereogram (Schmidt canvas) of poles of fractures of this study.

2014; Walter et al., 2018, 2019). During uplift phases in the Cretaceous, the faults' reactivation would drain upwards the $\mathrm{Ba}$ and $\mathrm{F}$ enriched brines that would mix with sedimentary basin brine rich in sulphate. This is marked by fluorite and then barite precipitations in fractures. In this model, fluids up-flows from the basement are very saline and hot, while sedimentary and meteoric waters are colder and of lower salinity. For some authors, precipitations in fault zones occurred continuously from Upper Permian to Upper Jurassic (Baatartsogt et al., 2007).

d. Late Cretaceous-Paleogene stage: This stage is related to the Paleogene rifting along NE-SW to NNE-SSW oriented fault systems (Staude et al., 2011; Burisch et al., 2017b). Barite-quartz-carbonates and barite-quartz-fluorite assemblages correspond to the main paragenesis observed in the Schwarzwald. Most of these mineralisation are accompanied by $\mathrm{Pb}$ ores, and more sparsely $\mathrm{As}, \mathrm{Zn}, \mathrm{Cu}$, $\mathrm{Bi}$, and $\mathrm{Ni}$ ores. The fluid salinity varies from 0 to $20 \mathrm{wt} . \%$, and homogenisation temperatures from 50 to $150{ }^{\circ} \mathrm{C}$ (Staude et al., 2009). Several Paleogene Mississippi Valley Type (MVT) deposits are referenced on the eastern border of the URG (Schwinn et al., 2006; Baatartsogt et al., 2007; Pfaff et al., 2010). e. Miocene-Pliocene stage: Salinity of $13-18 \mathrm{wt} . \%$, and homogenisation temperatures from 50 to $150^{\circ} \mathrm{C}$ (Staude et al., 2009) characterise the barite-quartz veins of this stage. Carbonate phases were also identified as late-stage mineralisations in the Schwarzwald district (Staude et al., 2012; Burisch et al., 2017b).

The fracture infills studied here likely belong to one or several of the three latter stages, as the studied sandstones of the Buntsandstein $\mathrm{Gp}$. are younger than the two first phases. These pathways which control present day fluid mixing, might have been active since the Miocene, as the URG kept the same structural organisation and stayed under similar regional stress (Schumacher, 2002; Reicherter et al., 2008).

\section{Material and methods}

Few datasets with a detailed structural background are available on the western shoulder and deep-seated of fracture mineralisations in the Buntsandstein Gp., despite their contribution to fracture permeability, especially regarding barite (Griffiths et al., 2016). A multi-disciplinary approach is developed to determine the source of fluids causing mineralisation within the fractures and filling the matrix. 


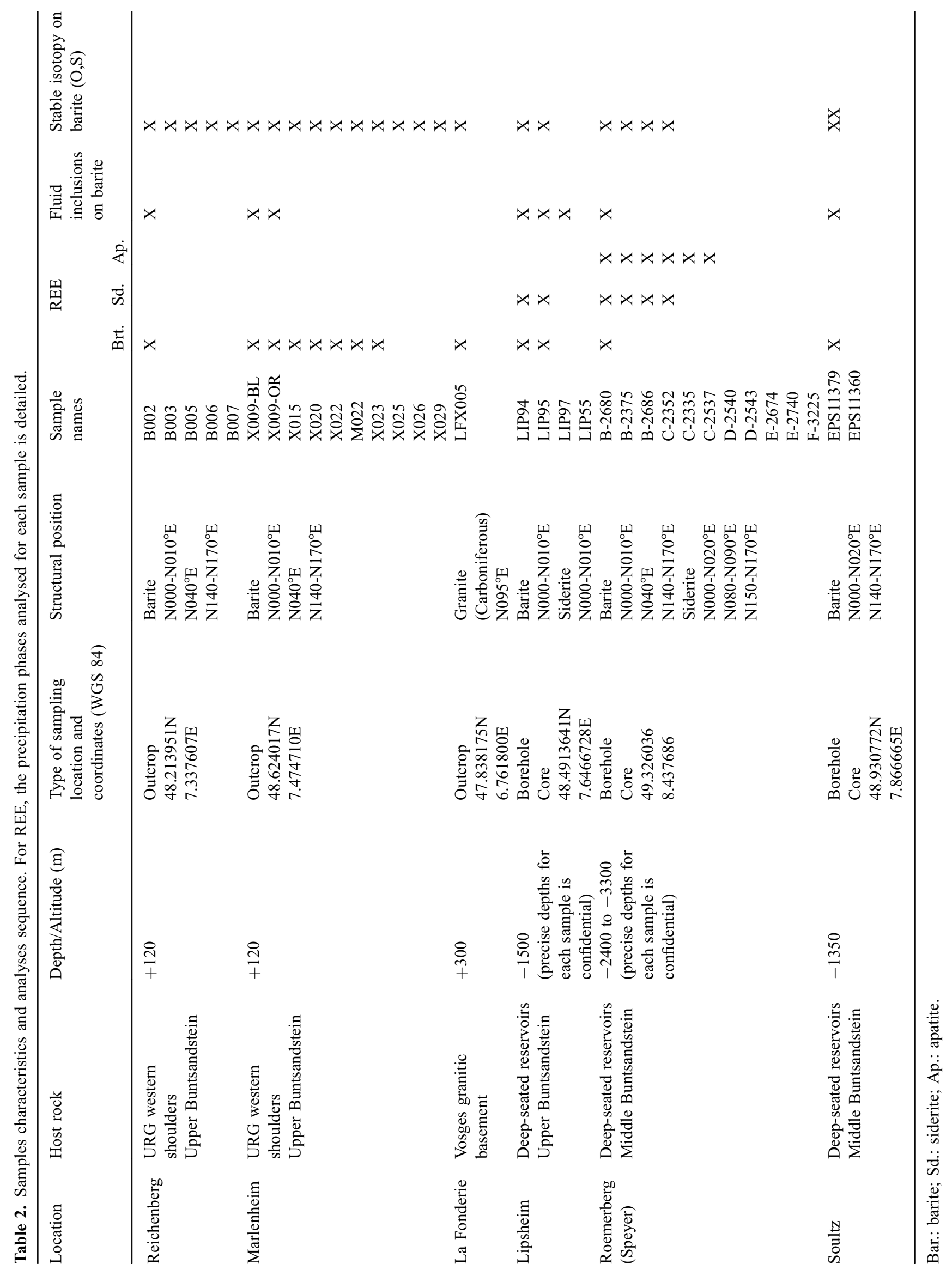


Table 3. $\delta^{34} \mathrm{~S}$ and $\delta^{18} \mathrm{O}$ bulk values obtained on barite.

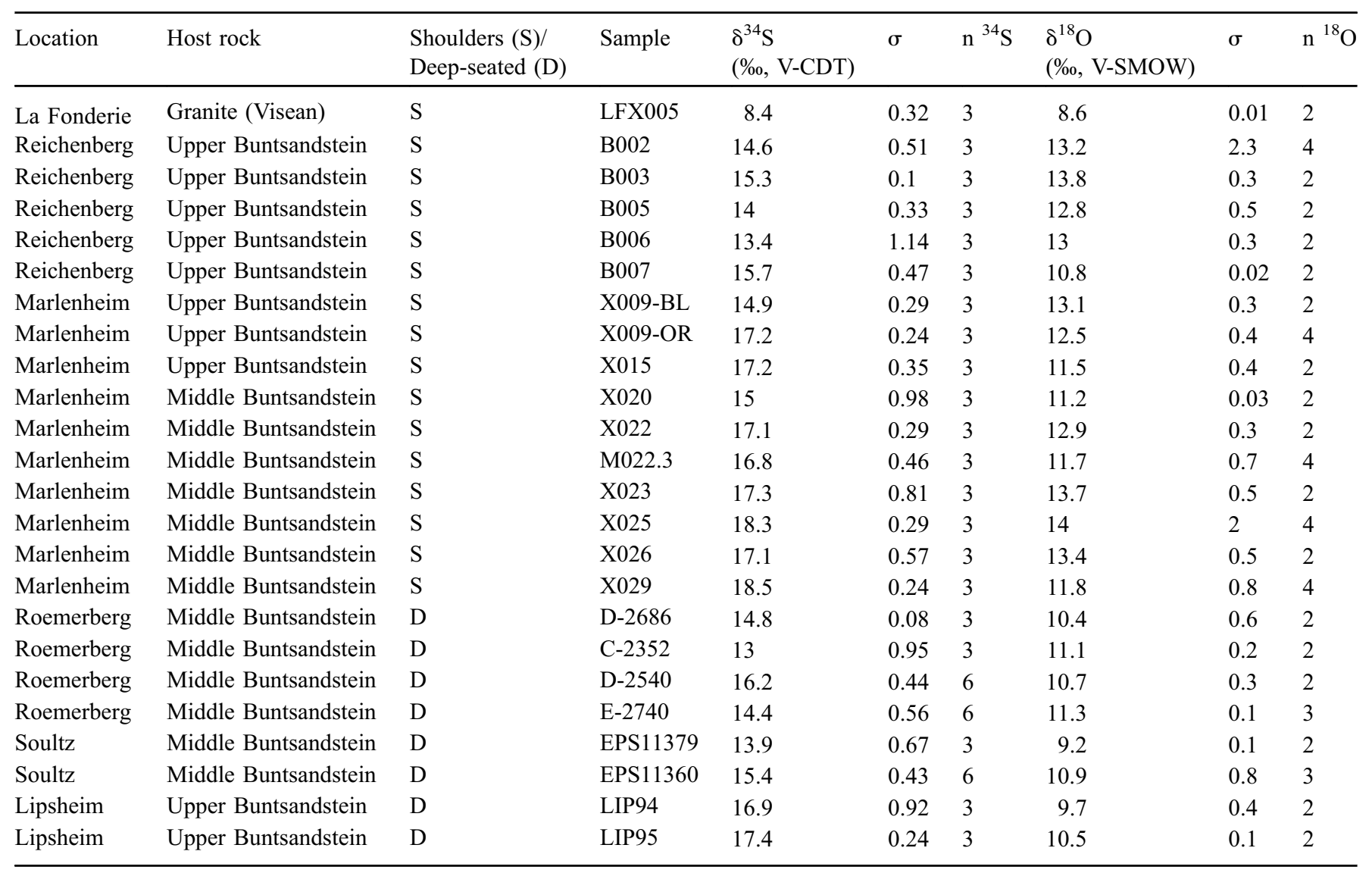

$\sigma$ : standard deviation; $\mathrm{n}^{34} \mathrm{~S}$ : number of analyses for $\delta^{34} \mathrm{~S} ; \mathrm{n}^{18} \mathrm{O}$ : number of analyses for $\delta^{18} \mathrm{O}$.

This approach was applied on samples from different localities, referenced on Figures 1 and 3, and Table 2.

Backscattered electron(BSE) and cathode-luminescence (CL) observations were performed on a hot cathode on Tescan VEGA3 SEM device with a current intensity of 15-17 nA and a voltage of $15 \mathrm{kV}$.

${ }^{18} \mathrm{O} /{ }^{16} \mathrm{O},{ }^{34} \mathrm{~S} /{ }^{32} \mathrm{~S}$ (from $\mathrm{SO}_{2}$ ) were determined using a Thermo Scientific MAT 253 stable isotope ratio mass spectrometer system (CRPG laboratory). For each sample, barite crystals were isolated, then powdered, and 2 to 6 tin capsules containing $1 \mathrm{mg}$ of the powdered material were analysed. The number of measurements per sample and the error associated with the measure is indicated in Table 3. In-situ ${ }^{34} \mathrm{~S} /{ }^{32} \mathrm{~S}$ were determined using Secondary Ion Mass Spectrometer(SIMS), Cameca IMS 1270 ion microprobe at the CRPG laboratory. The results are expressed with the conventional $\delta$ notation $v s$ V-SMOW (O) and CDT (S).

Bulk and in-situ $\delta^{34} \mathrm{~S}$ on barite mineralisations were measured on 24 samples across the Upper Rhine Graben to trace the fluid's potential source. Bulk isotope analyses on $\delta^{18} \mathrm{O}$ on the same samples coupled with fluid-inclusion microthermometry were used to estimate the temperature range of precipitation and deduce the fluid signature.
Fluid inclusions (FI) microthermometry was performed on an Olympus BX50 optical microscope, equipped with a Linkam MDS600 stage, within a temperature measurement range from -90 to $250^{\circ} \mathrm{C}$. Homogenisation temperatures $\left(\mathrm{T}_{\mathrm{h}}\right)$ were measured, and then samples were cooled down to $-90^{\circ} \mathrm{C}$. Ice melting temperature $\left(\mathrm{Tm}_{\text {ice }}\right)$ was measured during the reheating phase.

Temperature does not impact the REE distribution pattern. The composition in REE is not affected by further fluidcirculations after crystallisation, except for systems with an extremely high water/rock ratio (Azmy et al., 2011; Tostevin et al., 2016). Globally, REE are substituting for the metallic ion in the carbonate lattice, and remain stable during diagenesis (Tostevin et al., 2016). REE chemistry is thus an excellent tool to decipher the fluid origin.

REE chemistry was performed on 21 samples using LAICPMS, to characterise barite, carbonate, and apatite mineralisations. The device used is a GEOLAS Pro nanosecond excimer laser, with a $193 \mathrm{~nm}$ wavelength. He aliments the system, and induced plasma is analysed by an AGILENT 7500 mass spectrometer (GeoRessources laboratory, Université de Lorraine). NIST glass was used as standard, and quantification was calculated using internals standards, which combined EDS 
measured composition (SDD type EDS spectrometer) and WDS analysis (Oxford Wave WDS spectrometer) on a JEOL J7600F SEM (SCMEM, Université de Lorraine).

\section{Results}

\subsection{Petrography and mineralogy}

The analysed sandstones consist of fine to medium-grained sandstones belonging to the Buntsandstein Gp. Detrital grains are mostly composed by quartz (>85\%), feldspars (av. 12\%) and lithic fragments (av. 3\%). The fracture sampled apparent length varies from $5 \mathrm{~cm}$ to $3 \mathrm{~m}$, and their opening ranges from $100 \mu \mathrm{m}$ to $2 \mathrm{~cm}$. No difference in the major elementary composition between matrix and fracture siderite was detected from EDS analyses. Thus, all of these carbonates are qualified as siderite.

For the sample of granite, only the barite infill of the fracture was analysed. Macroscopically, the granite is a porphyric granite with amphibole and biotite (Granite des Ballons). An $\mathrm{N} 095^{\circ} \mathrm{E}$ oriented structure carries the mineralisation (Fig. 3C).

In the entire samples set, cathodoluminescence observations allowed to identify zonations neither in barite nor in siderite. For the latter, the high content in $\mathrm{Fe}$ can explain the non-luminescence.

Siderite mineralisationis localised within the matrix (sometimes with a nodular shape), in oil-bearing partially open fractures, and fully cemented fractures. Apatite crystals were observed in samples from deeply buried sandstones only. Siderites as fracture infills $(\mathrm{Sd} 2, \mathrm{Sd} 3)$ were observed only in samples from the centre of the basin (Roemerberg, Soultz, Lipsheim, Fig. 1). Samples from the URG shoulders and from sandstones that are currently deeply seated show barite mineralisation. Barite is mainly present as fracture infill (Figs. 4B-4E). Locally pervasive barite mineralisation occurs in Buntsandstein Gp. sandstones. When pervasive, barite mineralisation occupies pore space and seals quartz and feldspars overgrowths.

The structural feature orientations are as follows (Fig. 3D): the deformation bands have an $\mathrm{N} 140-\mathrm{N} 170^{\circ} \mathrm{E}$ orientation and were observed only in deep-seated sandstones. Deformation bands pre-date the fracture features geometrically (Fig. 4C).

These three fracture cementation phases are related to abnormal diagenetic evolution. The orientation of the fractures cemented by barites is restrained to the N000-N010 ${ }^{\circ} \mathrm{E}, \mathrm{N} 140-$ $\mathrm{N} 170^{\circ} \mathrm{E}$ intervals for deep-seated sandstones, and $\mathrm{N} 040^{\circ} \mathrm{E}$, N000-N010 ${ }^{\circ}$, N $140-\mathrm{N} 170^{\circ} \mathrm{E}$ within rift shoulders sandstones. Fractures containing barite remain mostly only partially cemented, with an average opening from $100 \mu \mathrm{m}$ to $25 \mathrm{~mm}$. The orientations of fractures cemented by siderite are N000$\mathrm{N} 010^{\circ} \mathrm{E}, \mathrm{N} 080-\mathrm{N} 090^{\circ} \mathrm{E}$ and $\mathrm{N} 140-\mathrm{N} 170^{\circ} \mathrm{E}$, and siderite often clogs the fracture porosity. The average fracture opening ranges from $50 \mu \mathrm{m}$ to $1 \mathrm{~cm}$.

The host-rock diagenesis consists of a feldspar and quartz syntaxial cementation phase, a matrix siderite cementation (Sd1) (Fig. 5), followed by illitisation and precipitation of apatite crystals in the illite mesh (Fig. 6A). This matrix diagenesis pre-dates the brittle deformation and fracture cementation by two siderite phases and one barite $(\mathrm{Sd} 2$, Bar, Sid3). Analysed sandstones are also affected by deformation bands (Fig. 4C) which concentrate apatite mineralisation (Fig. 6B).

The first fracture infills are constituted by quartz overgrowth on quartz detrital grains at the fracture border (phase I), based on the observed geometrical relationships between mineral phases. The second event is siderite precipitation ( $\mathrm{Sd} 2)$ (phase II), in the fractures, but also penetrative in the matrix pore network (Figs. 5E and 5F). The orientation of the fractures affected by these mineralising events is $\mathrm{N} 000-\mathrm{N} 010^{\circ} \mathrm{E}, \mathrm{N} 080-\mathrm{N} 090^{\circ} \mathrm{E}$ and $\mathrm{N} 140-\mathrm{N} 170^{\circ} \mathrm{E}$. This generation of siderite also presents authigenic apatite (Ap2) (phase II) crystals which appear to be cogenetic of the siderite precipitation. This first fracture cementation is followed by barite precipitation, with needle or platy shape (phase III), that may build bridges spanning along the fracture width (Figs. 4A, 4B, 4D and 4E). Barite mineralisation is limited to fractures oriented $\mathrm{N} 000-\mathrm{N} 010^{\circ} \mathrm{E}, \mathrm{N} 140-\mathrm{N} 170^{\circ} \mathrm{E}$. Barite needles also trap apatite crystals (Ap3) of small size $(<10 \mu \mathrm{m}$ length) in the fractures. The third generation of siderite ( $\mathrm{Sd} 3$ ) plugs the fractures (phase IV), in the orientations $\mathrm{N} 000-\mathrm{N} 010^{\circ} \mathrm{E}$ and $\mathrm{N} 140-\mathrm{N} 170^{\circ} \mathrm{E}$ and traps cogenetic apatite (Ap4) (phase IV).

\subsection{Isotopic composition}

The source of sulphur influences $\delta^{34} \mathrm{~S}$ signature. $\delta^{18} \mathrm{O}$ signature is influenced by the origin of the fluid and by the precipitation temperature of the mineral (Boschetti et al., 2011).

The $\delta^{34} \mathrm{~S}$ and $\delta^{18} \mathrm{O}$ isotopic compositions of barite have a broad spectrum from 8.6 to $14 \%$ for $\delta^{18} \mathrm{O}$ and from 8.4 to $18.5 \%$ for ${ }^{34} \mathrm{~S}$ (Fig. 7 and Tab. 3). In-situ $\delta^{34} \mathrm{~S}$ is in the same range as bulk isotopic composition measured on powdered samples.

La Fonderie's sample (LFX005), from a vein in the carboniferous granite, has a $\delta^{34} \mathrm{~S}$ value of $8.4 \%$. Samples from Reichenberg have $\delta^{34} \mathrm{~S}$ values ranging from 13.4 to $15.3 \%$. Samples from Marlenheim outcrops have $\delta^{34} \mathrm{~S}$ values ranging from 14.9 to $18.5 \%$. For Roemerberg samples, $\delta^{34} \mathrm{~S}$ is varying between 13 and $16.2 \%$. For Soultz samples, $\delta^{34} \mathrm{~S}$ is varying between 13.9 and $15.4 \%$. For Lipsheim samples, $\delta^{34} \mathrm{~S}$ is varying between 16.9 and $17.4 \%$.

La Fonderie's sample (LFX005) has a $\delta^{18} \mathrm{O}$ value of $8.6 \%$. For Roemerberg samples, $\delta^{18} \mathrm{O}$ is varying between 10.4 and $11.3 \%$. For Soultz samples, $\delta^{18} \mathrm{O}$ is varying between 9.2 and $10.9 \%$. For Lipsheim samples, $\delta^{18} \mathrm{O}$ is varying between 9.7 and $10.5 \%$. Samples from Marlenheim outcrops have $\delta^{18} \mathrm{O}$ values ranging from 11.2 to $14 \%$. Samples from Reichenberg have $\delta^{18} \mathrm{O}$ values ranging from 10.8 to $13.8 \%$.

Average $\delta^{34} \mathrm{~S}$ values are similar for samples coming from the shoulders and those coming from the central part of the basin while the average $\delta^{18} \mathrm{O}$ values for the shoulder samples are higher than those measured for samples of the central part of the basin (Fig. 8). Despite the large interval of $\delta^{34} \mathrm{~S}$ for each location, no zonation in $\delta^{34} \mathrm{~S}$ content could be identified on barite infills nor by in-situ analysis or cathodoluminescence observations. 

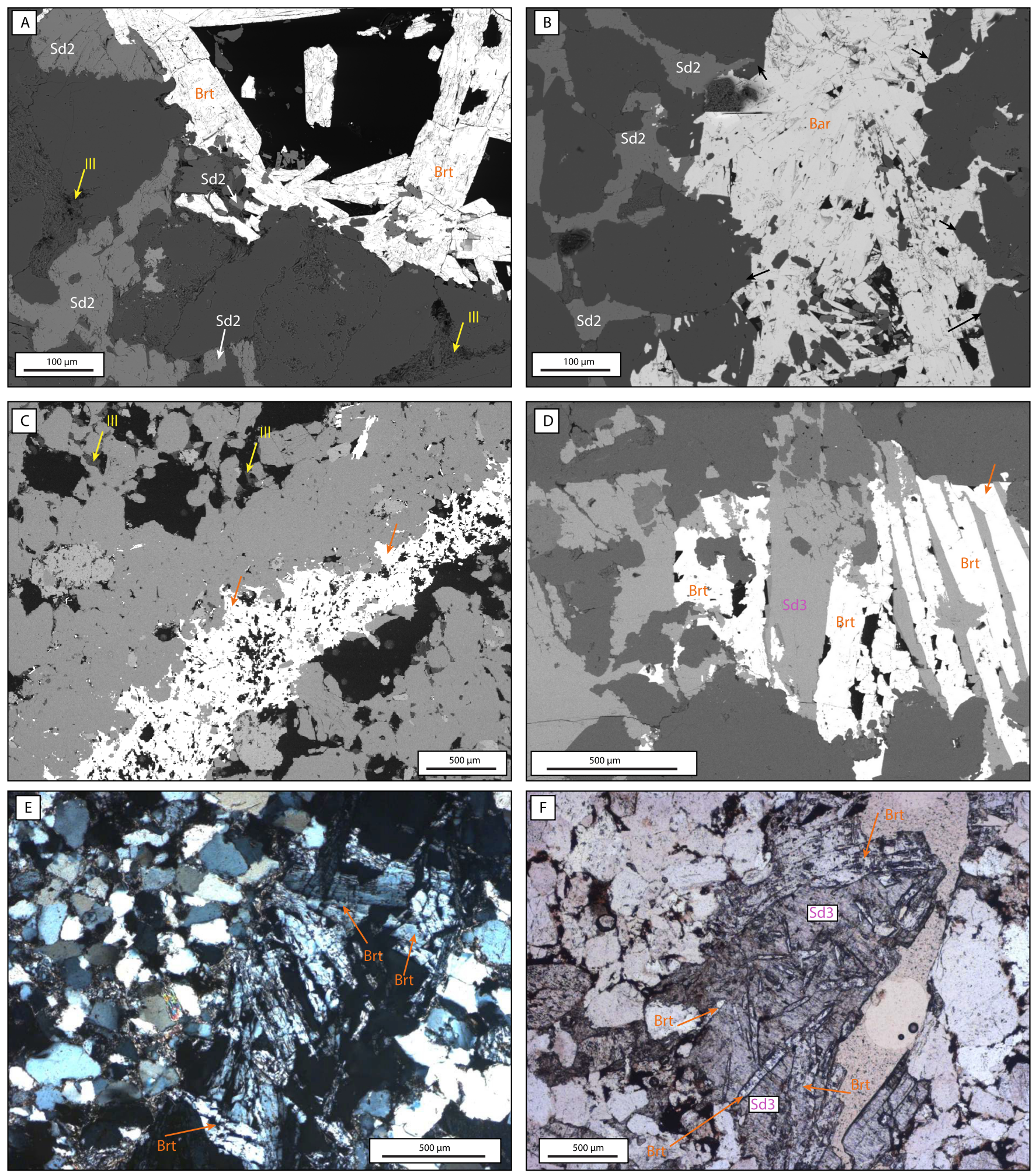

Fig. 4. Photomicrographs of barite cements. (A) SEM-BSE imaging of barite cement location in fracture, posterior to matrix pervasive siderite (Sd2) precipitation. Some pores are clogged by authigenic illite (Ilt) (yellow arrow). In black, the porosity (Sample C-2352, Roemerberg). (B) SEM BSE imaging of barite (Brt) filled fracture, and anterior siderite matrix pervasive cement (Sd2). Quartz detrital grains on the fracture borders show well authigenic quartz overgrowths (black arrows) In black, the porosity (Sample D-2540, Roemerberg). (C) SEM-BSE image of barite cemented fracture (orange arrow). The upper fracture border presents a cataclastic deformation of grains in black, the porosity (Sample B2375, Roermerberg). (D) SEM-BSE image of barite cross spanning partially cemented fracture. The fracture is entirely cemented by siderite cement (Sd3) In black, the porosity (Sample B-2686, Roemerberg). (E) Polarised transmitted light image of barite needle-shaped fracture cements (Sample C-2537, Roemerberg). (F) Transmitted light image of platy and needle-shaped barite cement. A posterior phase of siderite (Sd3) is present. The fracture remains partially open (sample D-2547, Roemerberg). 

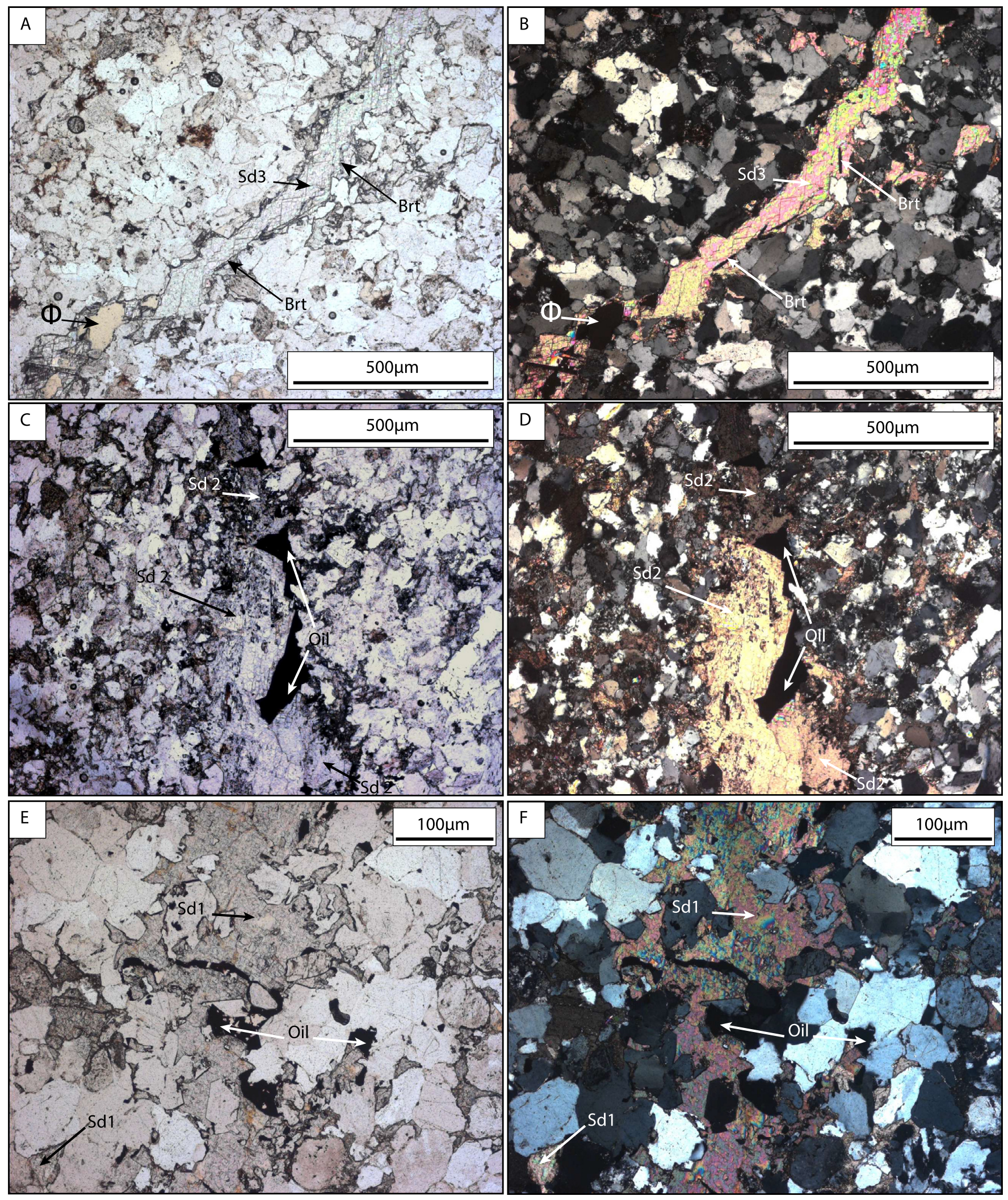

Fig. 5. Photomicrographs of siderite cements. (A) Natural transmitted light photomicrograph of a cemented fracture, barite (Brt) and posterior siderite (Sd3), containing no oil. Siderite crystal almost entirely plugs the fracture, except on the left bottom part of the image (Sample C2335, Roemerberg). (B) Transmitted polarised light photomicrograph of (A) (Sample C2335, Roemerberg). (C) Transmitted light photomicrograph of oil containing partially cemented fracture (Sd 2) (Sample E2674, Roemerberg). (D) Transmitted polarised light photomicrograph of (C) (Sample E2674, Roemerberg). (E) Transmitted light photomicrograph showing matrix siderite cement (Sd 1), and oil infill (Sample B-2680, Roemerberg). (F) Transmitted polarised light photomicrograph of (E) (Sample B-2680, Roemerberg). 

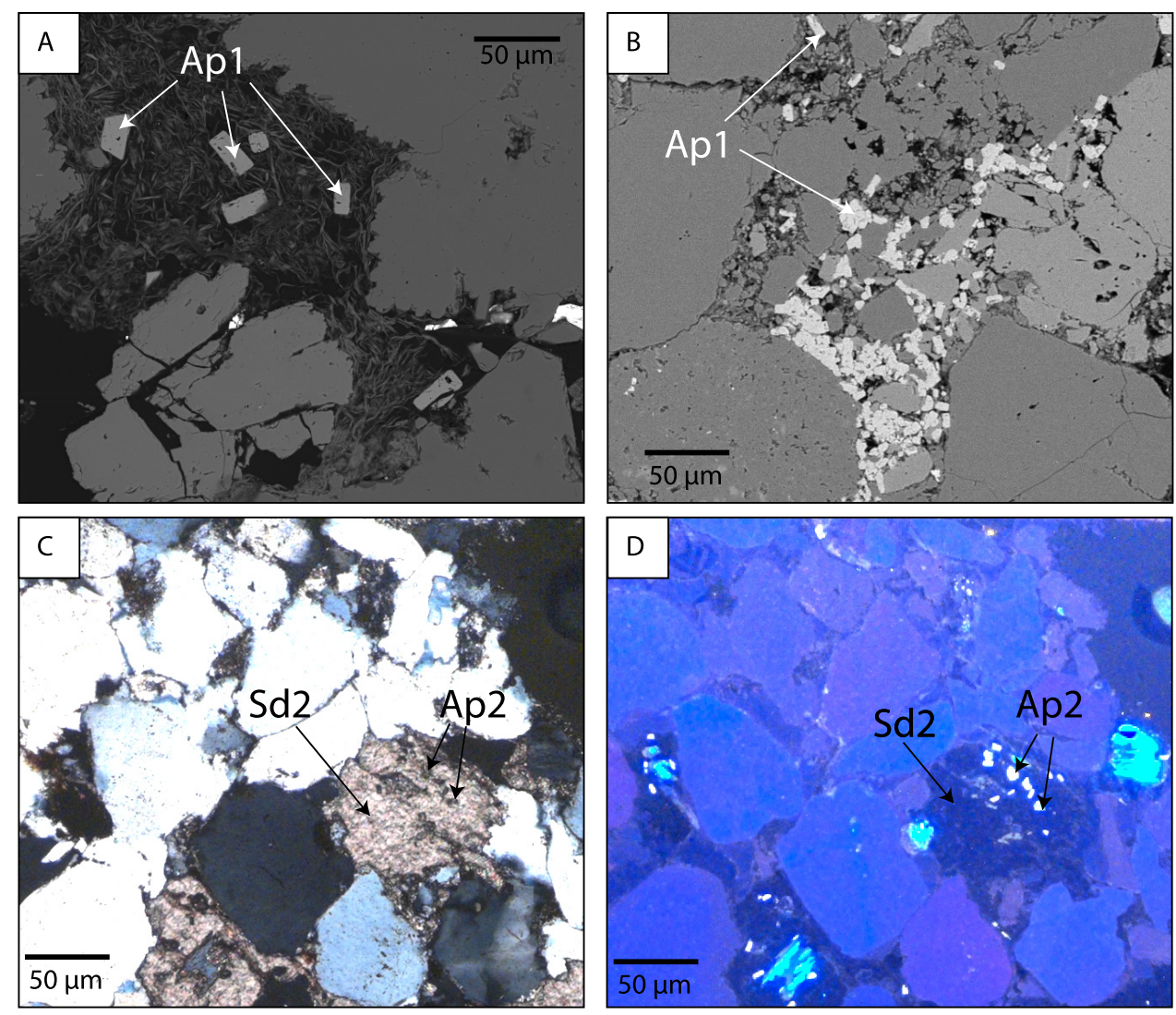

Fig. 6. Photomicrographs of apatite types. (A) Authigenic apatite (Ap1) crystals associated with an illite mesh plugging of the intergranular pore (Backscattered electron microscopy imaging) (Sample B-2680, Roemerberg). (B) Authigenic apatite crystals (Ap1) located in a micro cataclastic deformation band (backscattered electron microscopy imaging) (Sample F-3225, Roemerberg). (C) Transmitted polarised light photomicrograph of apatite crystals (Ap2) included in an intergranular pore siderite cement (Sd2) (Sample B-2375, Roemerberg). (D) Cathodoluminescent light photomicrograph of (C).

\subsection{REE content and anomalies}

REE pattern for barites is presented in Figure 8A. The Eu positive anomaly is likely to be an artefact due to the interference between $\mathrm{Eu}$ and $\mathrm{Ba}^{2+}$ during LA-ICPMS protocol. Therefore, these $\mathrm{Eu}$ anomalies for barite will not be discussed. The total REE amount in barite ( $\mathrm{REE}$ ) is $16.5 \mathrm{ppm}$ on average and ranges from 10.9 to $127 \mathrm{ppm}$. ¿REE is higher for barite from the shoulders than from the central URG (Fig. 8A). Using the LREE/HREE ratio expressed by the $\mathrm{La}_{\mathrm{CN}} / \mathrm{Lu}_{\mathrm{CN}}$ ratios, the distinction between samples coming from the shoulders and those sampled in the deep part of the basin is made. Central basin's samples are organised along a line with a $\mathrm{La}_{\mathrm{CN}} / \mathrm{Lu}_{\mathrm{CN}}$ ratio ranging from $1.10^{-1}$ to $5.10^{1}$ (Fig. 8B), while the shoulder samples are distributed above this line with higher $\mathrm{Lu}_{\mathrm{CN}}$ values.

Siderites have a mean $\Sigma$ REE of $55.9 \mathrm{ppm}$, and $\Sigma$ REE ranges from 0.1 to $408 \mathrm{ppm}$. Three generations of siderite were analysed, and generations 2 and 3 have two different microstructural contexts, e.g. matrix cement or fracture cement (Figs. 9A and 9B). Crystals belonging to Siderite 1, which only occur as matrix cement, have a typical sedimentary REE pattern, with a $\mathrm{La}_{\mathrm{CN}} / \mathrm{Lu}_{\mathrm{CN}}$ ratio relatively constant, around 10 for a large variability of $\mathrm{Lu}_{\mathrm{CN}}$ value. Despite the few minerals sampled, the second pattern, constituted by matrix siderite 2 containing authigenic apatite, has a bell shape, with moderate content in HREE and MREE. These siderites have a $\mathrm{La}_{\mathrm{CN}} / \mathrm{Lu}_{\mathrm{CN}}$ ratio between $4.10^{-1}$ and 3 .

Siderite 2 sampled in fractures, which contain apatite have a bell-shaped pattern, with high content in MREE and HREE, but total $\Sigma R E E$ value is higher than Siderite 2 sampled in the matrix. These siderites have a $\mathrm{La}_{\mathrm{CN}} / \mathrm{Lu}_{\mathrm{CN}}$ ratio evolving following a power-law versus $\mathrm{Lu}_{\mathrm{CN}}$, with $\mathrm{La}_{\mathrm{CN}} / \mathrm{Lu} \mathrm{CN}_{\mathrm{CN}}$ between $1.10^{-1}$ and 8 , for a $\mathrm{Lu}_{\mathrm{CN}}$ varying from 1 to $2.10^{1}$.

For Siderite 3, sampled in fully cemented fractures, the REE patterns also have a bell-shaped pattern, with depletion of LREE compared to fractures containing oil. La content can be varying from $6.10^{-6}$ to $8.10^{-1}$ compared to chondrite standard. For the fractures containing oil, $\mathrm{La}_{\mathrm{CN}} / \mathrm{Lu} \mathrm{CN}_{\mathrm{CN}}$ range from $2.10^{-2}$ to $1.10^{-1}$ (Fig. 9B).

Fully cemented fracture cements have a $\mathrm{La}_{\mathrm{CN}} / \mathrm{Lu} \mathrm{CN}_{\mathrm{CN}}$ ratio ranging from $2 \cdot 10^{-6}$ to 1 , with most points ranging from $6.10^{-4}$ to 1 , and they have the widest dispersion (Fig. 10). The REE pattern presents a bell shape on the three samples where apatite crystals are big enough to be measured, with high content in MREE (Eu: $10^{-3} \mathrm{ppm}_{\text {sample }} / \mathrm{ppm}_{\mathrm{CN}}$ ) (Fig. 10A). The total $\mathrm{REE}$ content is higher than $10^{3}$ compared to chondrite. The content in $\mathrm{La}$ is variable for apatite sampled in compaction 


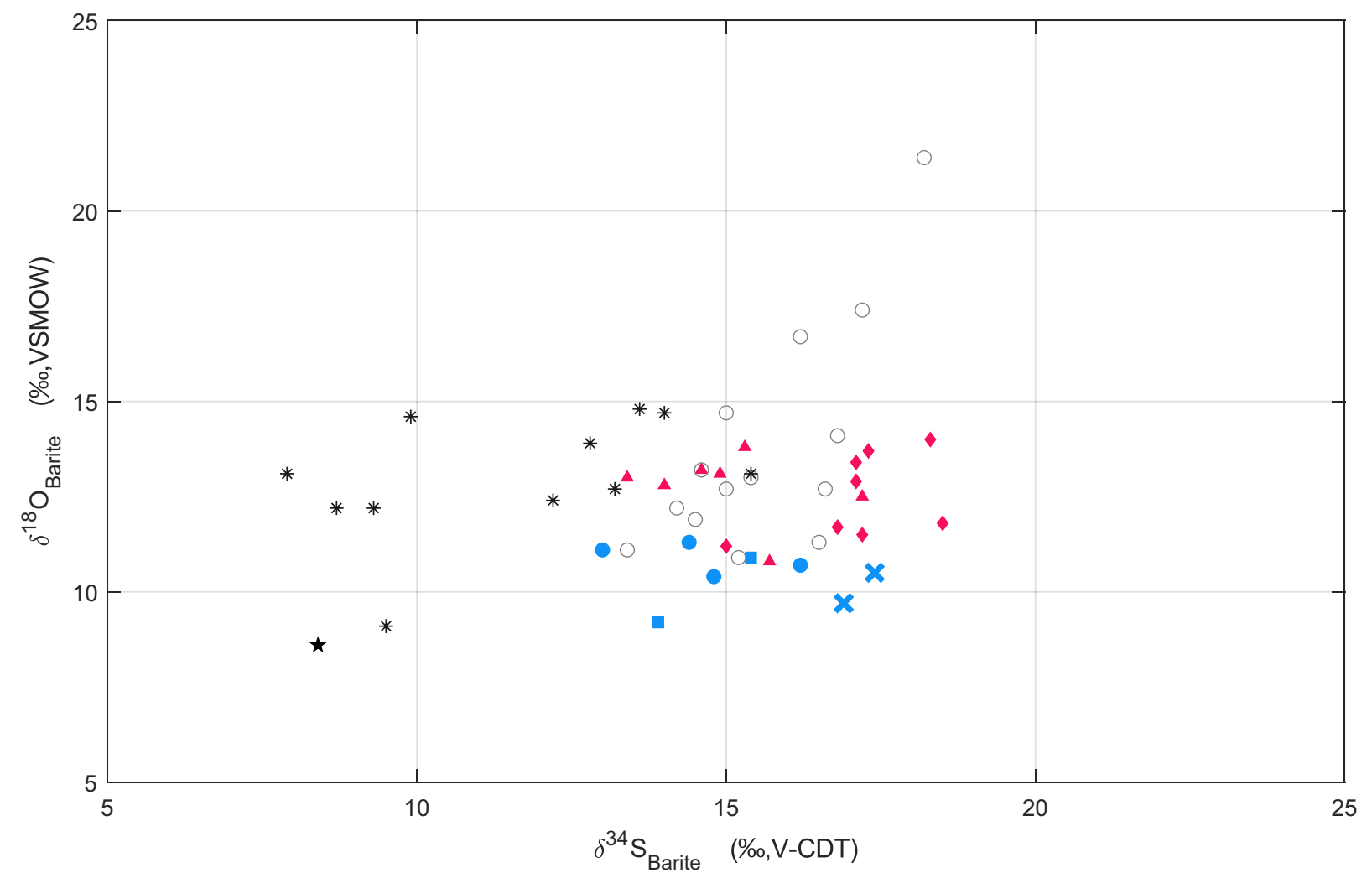

$\begin{array}{|ll|}\star & \text { Variscan Basement - La Fonderie (This study) } \\ & \text { Reichenberg (This study) } \\ & \text { Marlenheim (This study) } \\ & \text { Roemerberg (This study) } \\ & \text { Soultz (This study) } \\ & \text { Lipsheim (This study) } \\ * & \text { Sedimentary Upper Triassic sulphates (Boschetti et al., 2013) } \\ * & \text { Hydrothermal barite veins in Permian sandstones - Thuringer Basin (Majzlan et al., 2016) }\end{array}$

Fig. 7. Isotopic compositions of barite from veins.
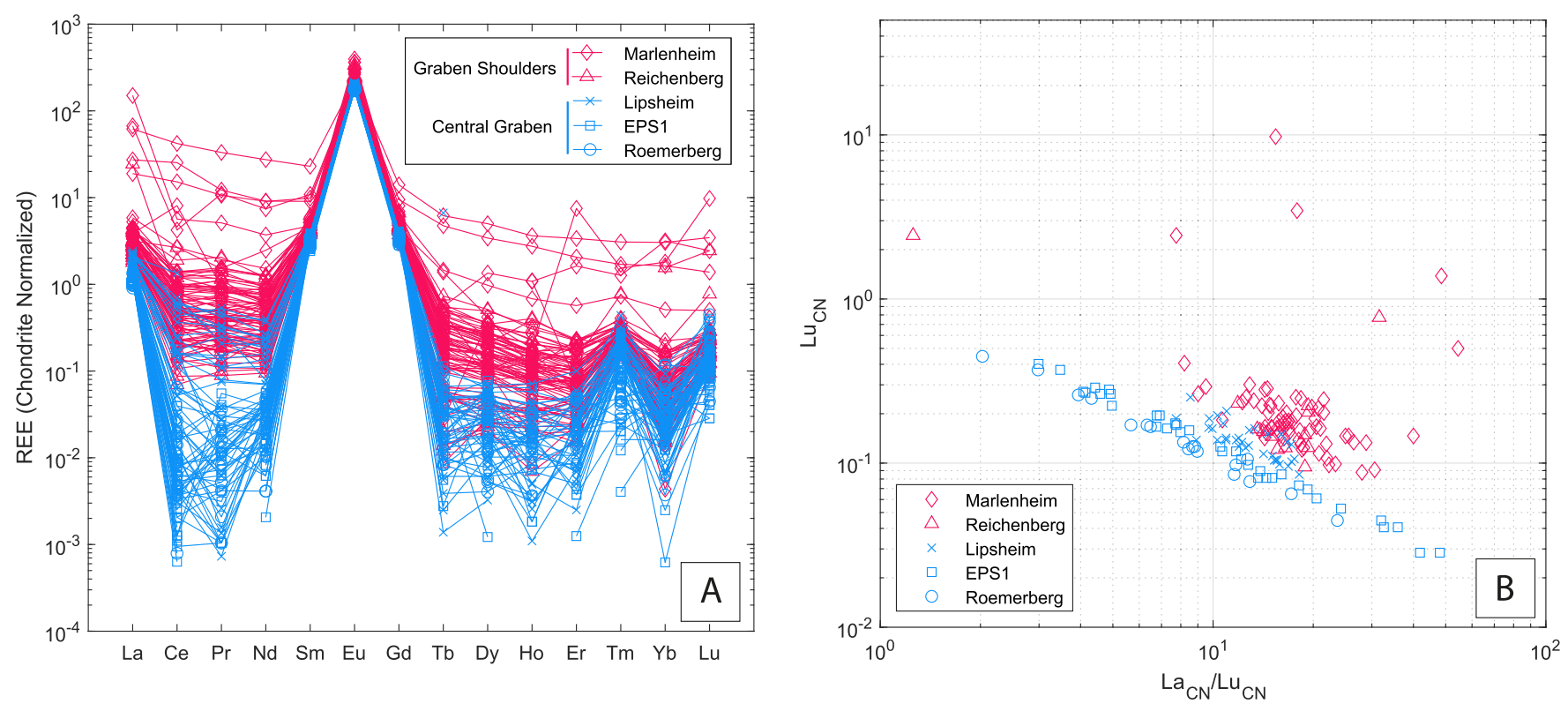

Fig. 8. REE patterns for barite. (A) Chondrite normalised REE pattern for barite. Standardisation values from Pourmand et al. (2012). (B) $\mathrm{La}_{\mathrm{CN}} / \mathrm{Lu}_{\mathrm{CN}} v s \mathrm{Lu}_{\mathrm{CN}}$ distribution for barite. 

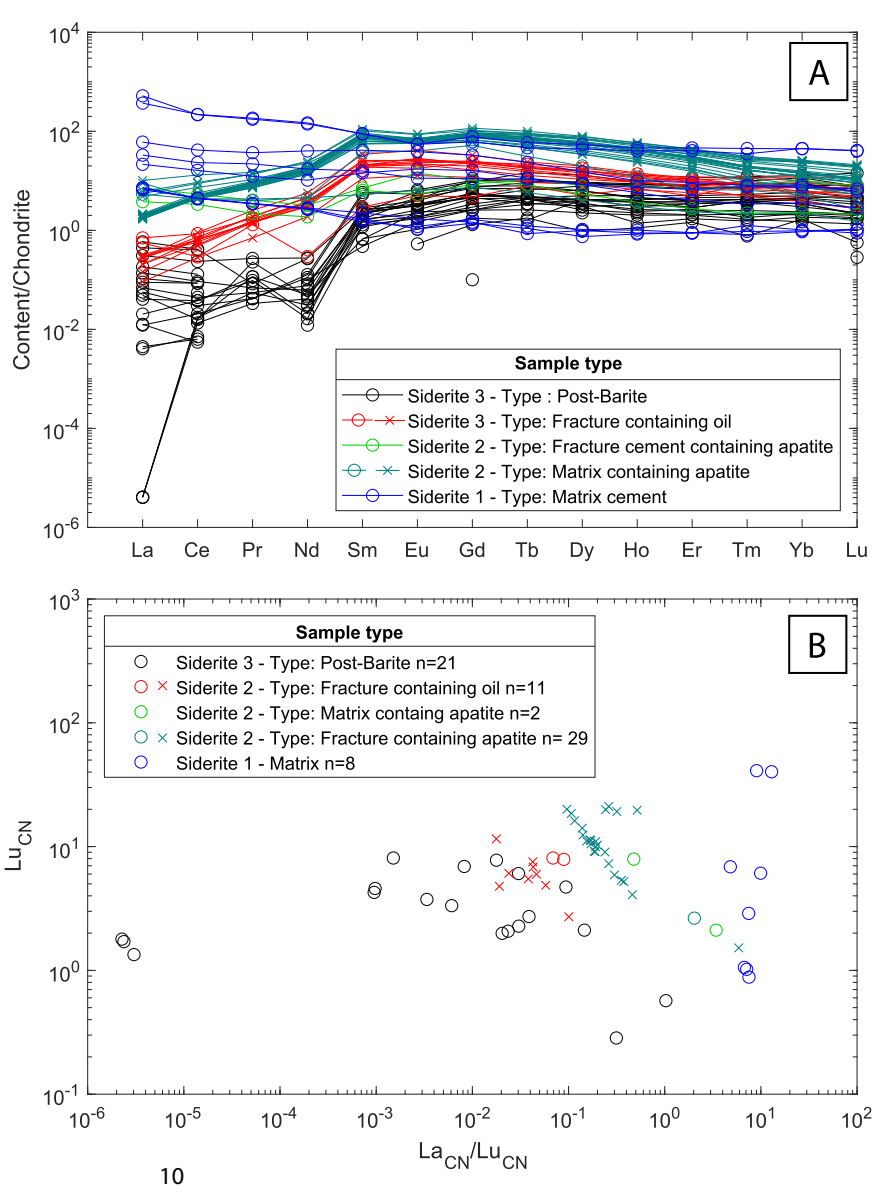

Fig. 9. REE patterns for the various generations of siderite. (A) REE pattern for siderite sorted by generation and textural feature. (B) $\mathrm{La}_{\mathrm{CN}} / \mathrm{Lu}_{\mathrm{CN}}$ distribution for siderite. $\mathrm{X}$ crosses represent samples from Lipsheim, and circle; samples from Roemerberg.

bands. For apatites sampled in fractures, the $\mathrm{La}_{\mathrm{CN}} / \mathrm{Lu}_{\mathrm{CN}}$ ratio ranges from $1.10^{-1}$ to $5 \cdot 10^{-1}$ (Fig. 10B).

\subsection{Microthermometry}

Microthermometry was performed on both siderite and barite samples. However, measurements on siderites were not successful because of leakage during the freezing step. Thus, only barite $T_{h}$ and $\mathrm{Tm}_{\text {ice }}$ distributions for analysed samples are used (Fig. 11).

The measured fluid inclusions size varies from 5 to $15 \mu \mathrm{m}$ long. Inclusions generally have ellipsoidal shape, either singular, isolated primary inclusion or forming pseudosecondary fluid inclusion plans. The inclusions are aqueous, as Raman spectroscopy detected no $\mathrm{CO}_{2}$. In sample $\mathrm{C} 335$ (Roemerberg), the pseudo secondary inclusions form fluid inclusions plans with co-existing hydrocarbon-bearing and aqueous inclusions.

In URG shoulder samples (e.g. X015 and X009 from Marlenheim, and B002 from Reichenberg), $\mathrm{T}_{\mathrm{h}}$ range from 140 to $240^{\circ} \mathrm{C}$, with a majority of $\mathrm{T}_{\mathrm{h}}$ restrained from 165 to $200^{\circ} \mathrm{C}$. $\mathrm{Tm}_{\text {ice }}$ ranges from -3.3 to $-0.6^{\circ} \mathrm{C}$, reflecting very low salinities (from 1.1 to 5.4 wt.\%eq. $\mathrm{NaCl}$ ). Soultz's sample
(EPS11379) has $\mathrm{T}_{\mathrm{h}}$ ranging from 110 up to $165^{\circ} \mathrm{C}$, and $\mathrm{Tm}_{\text {ice }}$ from -10.2 to $-0.2^{\circ} \mathrm{C}$. The fluids trapped in these inclusions have a low to moderate salinity ( 0.4 to $14.1 \mathrm{wt} . \%$ eq. $\mathrm{NaCl}$ ). Samples from Lipsheim's well (LIP 1495.28 and LIP1497.44) have a large interval of $\mathrm{T}_{h}$, from 80 up to $190^{\circ} \mathrm{C}$, with a major family of inclusions with av. $\mathrm{T}_{\mathrm{h}}$ of $140^{\circ} \mathrm{C}$. $\mathrm{Tm}_{\text {ice }}$ ranges from -24 to $-0.1{ }^{\circ} \mathrm{C}$, reflecting the fluid's varying salinity in the inclusions (from 1.9 to $25 \mathrm{wt} . \%$ eq. $\mathrm{NaCl}$ ). Roemerberg (C2335) sample has a large interval of $\mathrm{T}_{\mathrm{h}}$ from 100 to $150{ }^{\circ} \mathrm{C}$, and $\mathrm{Tm}_{\text {ice }}$ from -13.1 to $-9.7^{\circ} \mathrm{C}$. These $\mathrm{Tm}_{\text {ice }}$ reflect a salinity comprised between 13.6 and 17 wt.\%eq. $\mathrm{NaCl}$, equivalent to a moderate salinity of the fluids.

Two populations of inclusions emerge from the overall dataset. The first population with high $T_{h}$ ranging from 180 to $240^{\circ} \mathrm{C}$, with very low saline to non-saline fluids, differs from the second population of milder $\mathrm{T}_{\mathrm{h}}$ ranging from 80 to $150^{\circ} \mathrm{C}$, and with varying salinity, from very low salinity to high salinity. For the second population, the colder the $T_{h}$ is, the higher is the salinity.

The gaseous phases of inclusions within barite were also analysed with Raman spectrometry. $\mathrm{H}_{2} \mathrm{O}$ mainly composes the gas phases trapped. Neither $\mathrm{CO}_{2}$ nor $\mathrm{H}_{2} \mathrm{~S}$ were detected.

The samples from deeply seated fractured sandstones show mostly inclusions from the second family, whereas the samples from the URG shoulders have inclusions belonging to the first described family of inclusions. The sample from Roemerberg (C2335) also shows primary and pseudo-secondary oil trapping inclusions and inclusions plans, with $T_{h}$ from 100 to $120^{\circ} \mathrm{C}$, av. $110^{\circ} \mathrm{C}$. These oil containing inclusions belong to the same fluid inclusion plans as aqueous inclusions, which $\mathrm{T}_{\mathrm{h}}$ range from 115 to $135^{\circ} \mathrm{C}$.

\section{Discussion}

The data collected on barite, siderite, and apatite precipitation in the pre, syn and post-rift phases of the basin provides constraints on the source of the precipitated products, the nature of the fluids that allowed the transport of this material and the temperature of precipitation. These new elements, integrated with previously published data, serve to reassess the URG fluid circulation model.

\subsection{Paragenetic sequence}

The paragenetic sequence is available in Figure 12. The pre-rift sequence divides into three stages (all included in phase 0 ):

1 A first planar clay grain coating, within fine-grained sandstones of the Buntsandstein Gp. (Sizun, 1995; Haffen, 2012; Soyk, 2015; Bossennec et al., 2018). Early cementation ( $\mathrm{Sd} 1)$ forms nodules and calcrete horizons associated with the development of soils on sand deposits (Haffen, 2012; Soyk, 2015). An early syntaxial feldspar overgrowth around detrital feldspar grains takes place (Soyk, 2015).

2 Precipitation of syntaxial quartz overgrowths on the border of detrital quartz grains, which is concomitant with feldspar illitisation (Soyk, 2015), and is probably fed by 

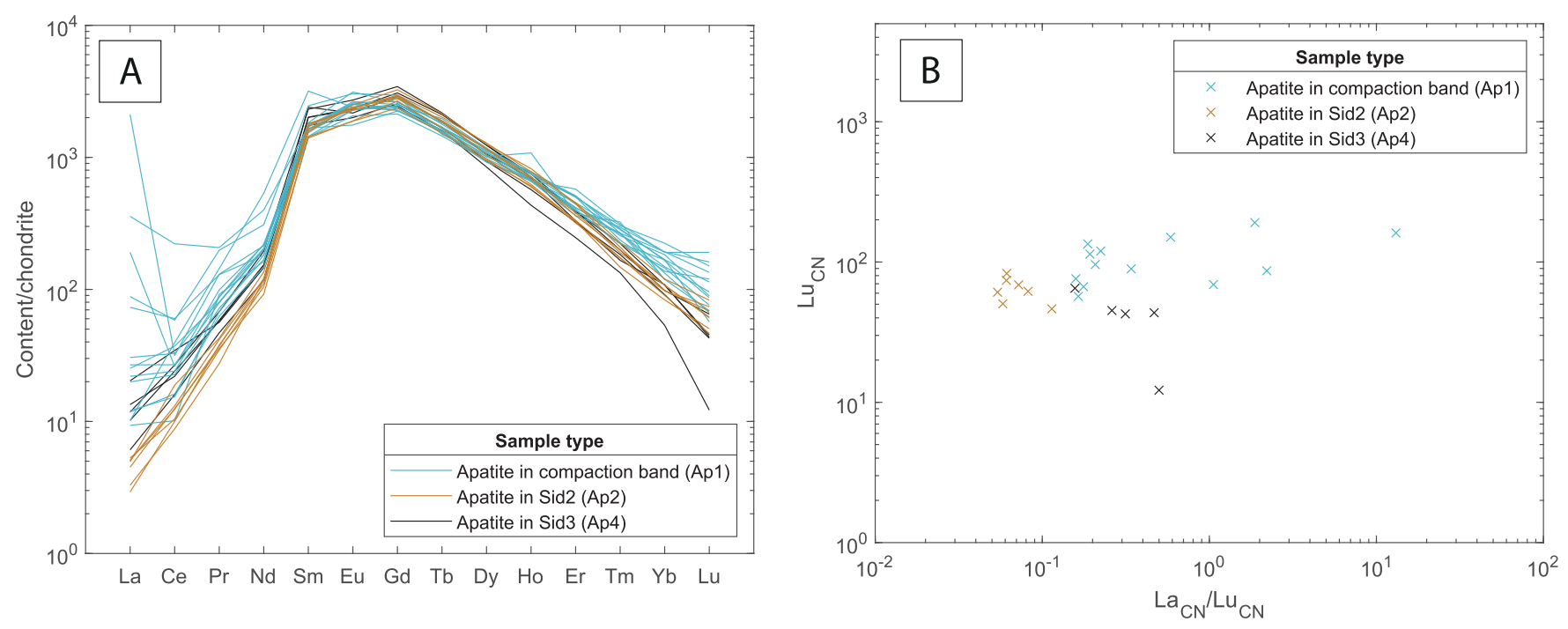

Fig. 10. REE patterns for apatite. (A) REE content normalised to chondrite, normalised against chondrite, of apatite crystals from LA-ICPMS. (B) $\mathrm{La}_{\mathrm{CN}} / \mathrm{Lu}_{\mathrm{CN}}$ distribution for apatites. All samples with analysed apatite originate from Roemerberg.

solutes originating from chemical compaction of quartz grains, which takes place in surrounding layers (Blaise et al., 2016).

3 Second feldspar overgrowth and authigenic illite precipitation (Bossennec et al., 2018). These last stage illites are tracing hydrothermal fluid circulations during Jurassic (Blaise et al., 2016; Clauer et al., 2008; Schleicher et al., 2006a, 2006b). The fracture infill observations suggest a paragenesis within the sandstones that completes the paragenetic sequence previously published. Four phases mark this fracture paragenesis.

Phase (I), with the deformation bands, forms first and present, in some samples, a concentration of authigenic apatite minerals (Fig. 6). Quartz overgrowths on quartz detrital on fracture borders also take place. During phase(II), siderite $(\mathrm{Sd} 2)$ precipitates in every fracture direction and is penetrative into the surrounding matrix, cogenetic with apatite. At phase (III), barite precipitates, cogenetic with apatite, mainly in $\mathrm{N} 000-\mathrm{N} 010^{\circ} \mathrm{E}, \mathrm{N} 040^{\circ} \mathrm{E}$ and $\mathrm{N} 140-170^{\circ} \mathrm{E}$ orientations. Then, the last siderite (post-barite) fracture cementation occurs (phase IV), trapping the last apatite generation (N000-N010 ${ }^{\circ} \mathrm{E}$, $\mathrm{N} 040^{\circ} \mathrm{E}$ and $\mathrm{N} 140-170^{\circ} \mathrm{E}$ orientations). The lack of siderite in outcrop samples may be the sign of carbonates dissolution, from which Fe-Mn oxides remnants are observed in several outcrops (Soyk, 2015).

Fracture diagenesis is limited to quartz and barite precipitation on the shoulders, whereas the paragenetic sequence is complete within deep-seated sandstones.

\subsection{Origin of the fluids}

The new chemical data gathers various information on the fluids' origin. Barite mineralisations are present on the URG shoulders and within deep-seated reservoirs, but have different precipitation contexts (temperature, fluid origin).

\subsubsection{Barite isotopic signature}

The $\delta^{34} \mathrm{~S}$ composition of the samples ranges from 10 to $18 \%$, with an average of $15.5 \%$ (Fig. 7). These values are like the ones published by previous studies on hydrothermal mineralisations of barite, along the northern fault system separating the URG from the Taunus Mountains (Loges et al., 2012) and on fractures and veins sampled in the Schwarzwald (Schwinn et al., 2006). Several sulfur sources are identified and comprise sulfides and sulfates, such as early diagenetic pyrite in the Middle Triassic limestone with isotopic values from -36.0 to $-7.6 \%$, Sulfate from the Middle Triassic, of which $\delta^{34} \mathrm{~S}$ values are $18.5-21.6 \%$ (Staude et al., 2011) or sulfate from the Upper Triassic with values ranging from 14.3 to $17.4 \%$ (Boschetti et al., 2011; Boschetti, 2013). Values from Oligocene URG sediments are $11.2-13.8 \%$ according to Staude et al. (2011), but the 20-20.6\% interval is typical for Tertiary sedimentary rocks, according to Loges et al. (2012).

In detail, analysed barite could differentiate into two groups using the $\delta^{18} \mathrm{O}$ values. Those with values lower than $12 \% \delta^{18} \mathrm{O}$, the samples from Lipsheim, Soultz and Roemerberg came from the deep part of the basin. Those with values upper than $12 \% \delta^{18} \mathrm{O}$ came from the shoulders.

The jointed $\delta^{18} \mathrm{O}$ and $\delta^{34} \mathrm{~S}$ signature of the barite cement are in accordance to Upper Triassic evaporitic sulphates origin, even if a light contribution of the Cenozoic sediments or primary sulfide is possible. This hypothesis of a Triassic sedimentary source for brines is also suggested for the Schwarzwald mineralisations (Bons et al., 2014; Walter et al., 2016). These evaporitic horizons are most probably the sulphur source for barite within fractures of the Buntsandstein Gp. sandstones, for mineralisations located on the rift shoulders, and within deep-seated sandstones. These conclusions agree with the current brines sampled in wells within the URG that show similar $\delta^{34} \mathrm{~S}$ (Sanjuan et al., 2016). 


\section{Fluid inclusions distributions}
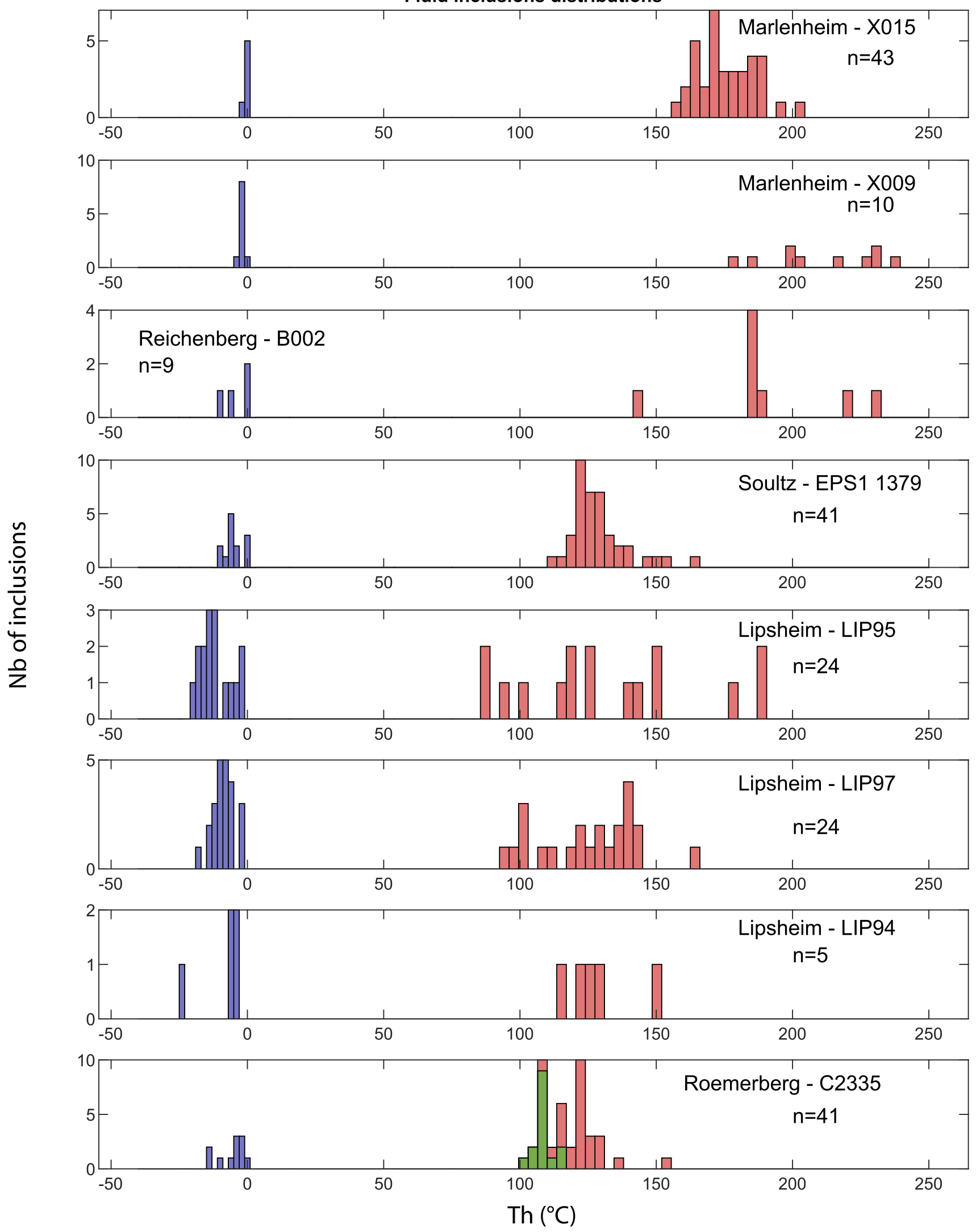

Fig. 11. Distributions of $T_{h}$ and $\mathrm{Tm}_{\mathrm{ice}}$ for barite on analysed samples (pink for $\mathrm{Th}$, blue for $\mathrm{Tm}_{\mathrm{ice}}$, and green for $\mathrm{T}_{\mathrm{h}}$ in hydrocarbons bearing inclusions). 


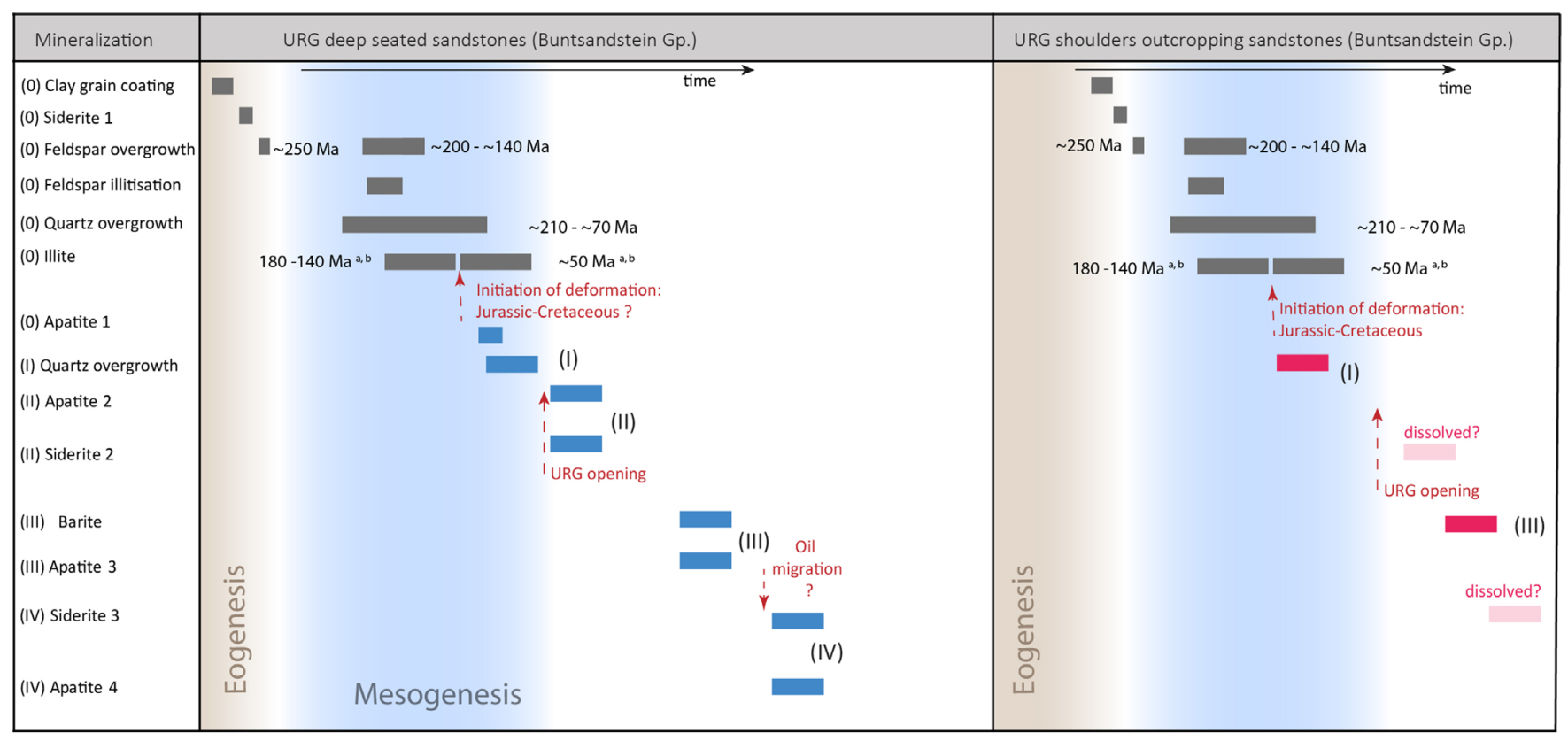

Fig. 12. Parageneses of mineralising events in the fracture network within the Buntsandstein Gp. sandstones. One paragenesis sequence is extracted for each structural sample context, e.g. deep-seated sandstones, and shoulder outcropping sandstones. In grey, the diagenetic sequence affecting the sandstone before deformation (e.g. first deformation bands); in blue, events affecting the deep-seated reservoirs and in pink the outcrops on URG shoulders. Reference for dating a: Blaise et al. (2016); b: Schleicher et al. (2006a, 2006b). Phases 0, I, II, III and IV are defined in the text.

\subsubsection{Barite, Siderite and Apatite REE composition}

The diagrams, presented Figure 13, are divided into 5 fields, describing the following conditions: In the field IIa, apparent negative Ce anomaly, due to positive La anomaly; in the field IIb, a negative La anomaly produces an apparent positive anomaly in $\mathrm{Ce}$; in the field IIIa, the positive Ce anomaly is real; in the field $\mathrm{IIIb}$, the negative Ce anomaly is real; in the field IV, the positive $\mathrm{La}$ anomaly is hiding a positive Ce anomaly.

The Ce anomaly for barites from the graben's shoulders and the Central Graben reflects a considerable variation in positive and negative $\mathrm{Ce}$ anomalies. Sampled barites belong to domains IIa, IIIb and IV (Fig. 13A). The La anomaly is less positive for shoulders samples than for basin's ones. Some barite crystals have a marine signature (from the Ce negative anomaly), and some barites have a positive $\mathrm{Ce}$ anomaly masked by a positive La anomaly.

In the central part of the basin, barite mineralisations are associated with siderites and apatites. A negative Ce anomaly signs the contribution of seawater derived brine as mineralising fluid, and the hidden positive La anomaly is a characteristic of authigenic carbonate (Dolníček et al., 2014).

The first generation of siderite, located in the matrix, is included in the domain IIa and has a typical diagenetic signature, issued from marine brine (negative Ce anomaly). These marine brines are likely to be infiltrated during the Late Triassic, as it is the case on the Schwartzwalder's shoulder (Walter et al., 2019). Siderites of the next phases $(\mathrm{Sd} 2$ and $\mathrm{Sd} 3)$ have $\mathrm{Ce}$ and $\mathrm{La}$ anomalies in the domain IV and sign their diagenetic character. The interactions with siliciclastic material from the host-rock may explain the less negative Ce anomaly (Carpentier et al., 2014). However, some samples located in fully cemented fractures belong to the domain IIIb.

None of the siderite sampled present a strong Eu anomaly, suggesting that they are not influenced by hydrothermal activity. Usually, for carbonates, a positive Eu anomaly is a characteristic feature of high-temperature hydrothermal precipitation (Bau et al., 2003; Tostevin et al., 2016).

These siderite mineralisations ( $\mathrm{Sd} 2$ and $\mathrm{Sd} 3$ ) can contain apatite crystals. Positive anomalies in $\mathrm{Ce}$ and $\mathrm{La}$ mostly characterise sampled apatite crystals, with $(\mathrm{Ce} / \mathrm{Ce} * \mathrm{SN}, \mathrm{Pr} /$ Pr*SN) belonging to domain IV (Fig. 13B). The La anomaly of apatite also hides here a positive Ce anomaly. A majority of analysed apatites crystals have Eu anomaly around 1, with only a few samples with positive Eu anomaly. This anomaly is typical for diagenetic apatite as Eu does not fractionate under $200^{\circ} \mathrm{C}$ (Joosu et al., 2016). With an MREE enriched bellshaped pattern, $\mathrm{La}, \mathrm{Ce}$, and $\mathrm{Eu}$ anomaly sign a diageneticsedimentary origin of the brine (Göb et al., 2013).

The main limiting criteria to form apatite is the presence of $\mathrm{P}, \mathrm{F}$ and $\mathrm{Ca}$. These elements can be supplied by feldspar alteration from the basement, from compaction processes during diagenesis, and felspar grain dissolution (McConnell, 1973; Shields and Stille, 2001; Joosu et al., 2016). The source and precipitation mechanisms of P and REE can explain the bell-shaped and the observed enrichment in MREE. During the burial, REE and P can be released in the pore waters by the reductive dissolution of $\mathrm{Fe}-\mathrm{Mn}-$ oxides and oxyhydroxides (Haley et al., 2004; Joosu et al., 2016). Diagenetic phosphates REE spectrums often exhibit a bell-shape, due to MREE enrichments (Joosu et al., 2016; Tostevin et al., 2016). These oxides and oxyhydroxides can also retain Ce (Caetano et al., 2009), and are frequently associated with smectite on grain 

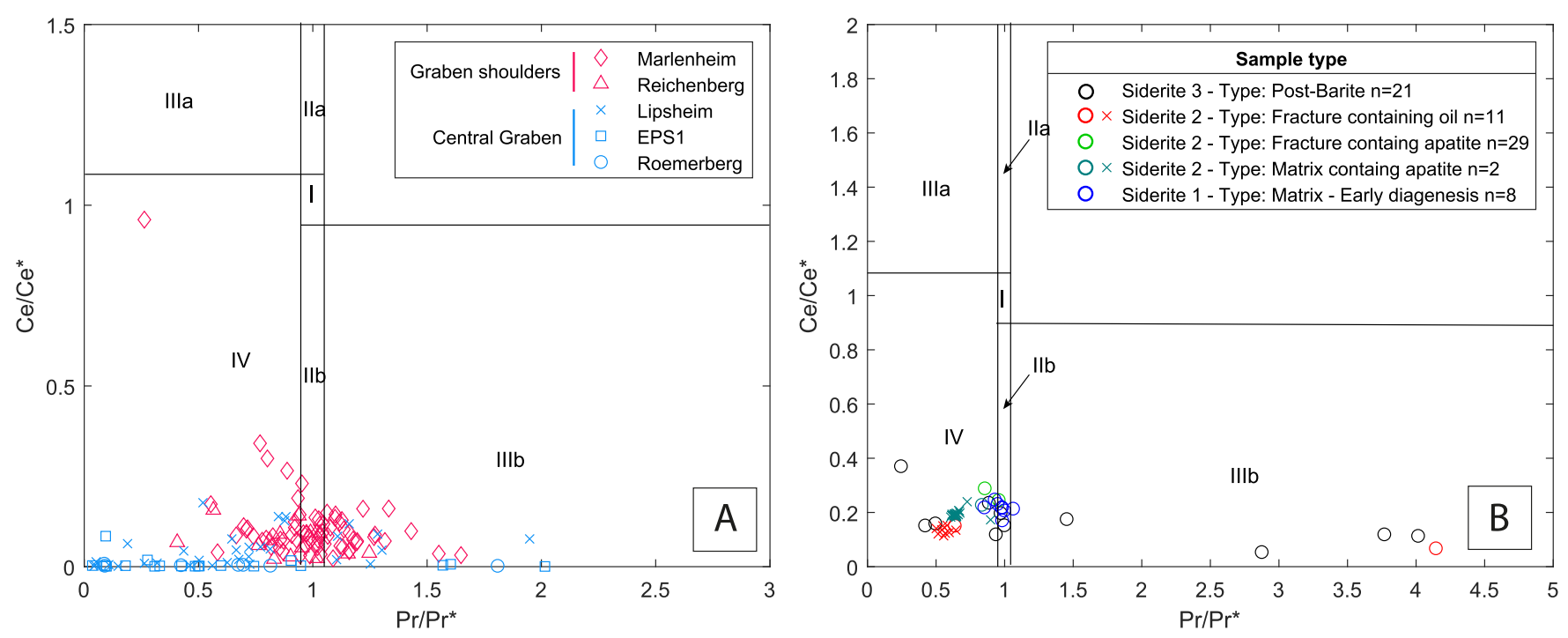

Fig. 13. Cerium and Lanthanum anomalies represented on a Ce/Ce* ${ }_{S N} v s$ Pr/Pr* ${ }_{S N}$ diagrams after Bau and Dulski (1996). (A) For barite. (B) For siderite, where " $x$ " crosses represent samples from Lipsheim, and circle samples from Roemerberg. See text for the domains definition.

coating in the early stages of diagenesis of the Buntsandstein Gp. sandstones (Bossennec et al., 2018; Soyk, 2015). The burial under reducing conditions of these coatings could be a potential source for the element forming diagenetic apatite in sandstones (Soyk, 2015). This aspect of phosphor source for apatite needs further investigation.

Overall, this signature suggests a strong role of basin fluids as a source for barite, siderite and apatite mineralisations. The REE pattern and anomalies in $\mathrm{La}, \mathrm{Ce}$, and $\mathrm{Eu}$ on barite, siderites and apatites sign the main role of sedimentary brines as the source of matter for the mineralisations. Fluids with diagenetic or basement origins interacted and induce variations of REE signatures.

The fluid-mixing pattern is observed only in samples from deep-seated reservoirs, located in the buried part of the URG, e.g. Roemerberg, Soultz or Lipsheim samples. This observation suggests that sedimentary brines, influenced by seawater trapped in sedimentary formations, are more involved in the barite precipitation process in the centre of the basin than along its shoulders. The rift shoulders circulations are mainly driven by hot, low to non-saline fluids, and the mixing rate is lower in faults bordering the shoulders.

\subsubsection{Fluid typing}

Jointed analysis of the IF data and $\delta^{18} \mathrm{O}_{\text {barite }}$ measured on barite mineralisation, is used to determine the fluid origin and the temperature conditions for precipitation (Figs. 14 and 15).

The IF study allows to distinguish two different poles of fluids. Inclusions from the sampled fractures of the URG border faults, such as in Reichenberg or Marlenheim, are characterised by high $\mathrm{Tm}_{\text {ice }}$ (close to $0{ }^{\circ} \mathrm{C}$ ) and high $\mathrm{T}_{\mathrm{h}}$ from 160 to $240^{\circ} \mathrm{C}$. Samples from deeply seated fractures present two types of fluid inclusions, a) "cold" $\mathrm{T}_{\mathrm{h}}$ (from 80 to $110^{\circ} \mathrm{C}$ ) and low $\mathrm{Tm}_{\text {ice }}\left(-22\right.$ to $\left.-10^{\circ} \mathrm{C}\right)$, reflecting saline and mild temperature brines, and b) intermediate $\mathrm{T}_{\mathrm{h}}\left(140-150^{\circ} \mathrm{C}\right)$ and with high $\mathrm{Tm}_{\text {ice }}\left(-5\right.$ to $\left.0{ }^{\circ} \mathrm{C}\right)$, reflecting mild temperature and low salinity fluids. FI of samples from deep seating sandstones reflect the trend observed for barite in veins sampled in the Buntsandstein Gp. sandstone, and in the underlying basement (Dubois et al., 1996), and from hydrothermal carbonate mineralisation events reported for the end-member of low-salinity and $80-110^{\circ} \mathrm{C}$ fluids (Pfaff et al., 2010).

The FI from samples located on the rift shoulders (e.g. Marlenheim, Reichenberg) reflect the hot end-member of hydrothermal calcite sampled in the Schwarzwald (Pfaff et al., 2010), the quartz in veins from Soultz (Dubois et al., 1996; Cathelineau and Boiron, 2010) the Schwarzwald quartz (Baatartsogt et al., 2007) and the "cold" low salinity endmember of post Variscan barite sampled in the Schwarzwald (Schwinn et al., 2006).

The $\mathrm{Tm}_{\text {ice }}$ of the studied samples do not reach the low values of Schwarzwald hydrothermal calcites (Staude et al., 2012) nor the pattern of barites from the Thuringer Basin (Majzlan et al., 2016).

Coupled with the FI study, the oxygen isotopic composition of barite helps estimate mineralising fluids' isotopic composition.

Following the equation (1) (Kusakabe and Robinson, 1977), a temperature of isotopic equilibrium is calculated for a supposed isotopic composition of the fluid, based on the measured isotopic composition of the precipitated mineral.

$$
\begin{gathered}
1000 \ln \alpha^{18} \mathrm{O} /{ }^{16} \mathrm{O}_{\text {barite-water }} \text { barite-water } \\
=3.01 *\left(10^{6} / T^{2}\right)-7.3 \pm 0.1 .
\end{gathered}
$$

Calculated temperatures of equilibrium are compared to measured fluid inclusion homogenisation temperatures (Fig. 14).

The $\delta^{18} \mathrm{O}$ of the analysed barite crystals have a wide dispersion from 9.2 to $13.8 \%$. Barites sampled in the deepseated sandstones have a lower $\delta^{18} \mathrm{O}$ than the barites sampled on the URG shoulders

The identified fluids are:

1 low-saline fluids, with high $\mathrm{T}_{\mathrm{h}}\left(180\right.$ to $\left.240{ }^{\circ} \mathrm{C}\right)$, which are associated with $\delta^{18} \mathrm{O}_{\text {barite }}$ from 9 to $17 \%$, and most 


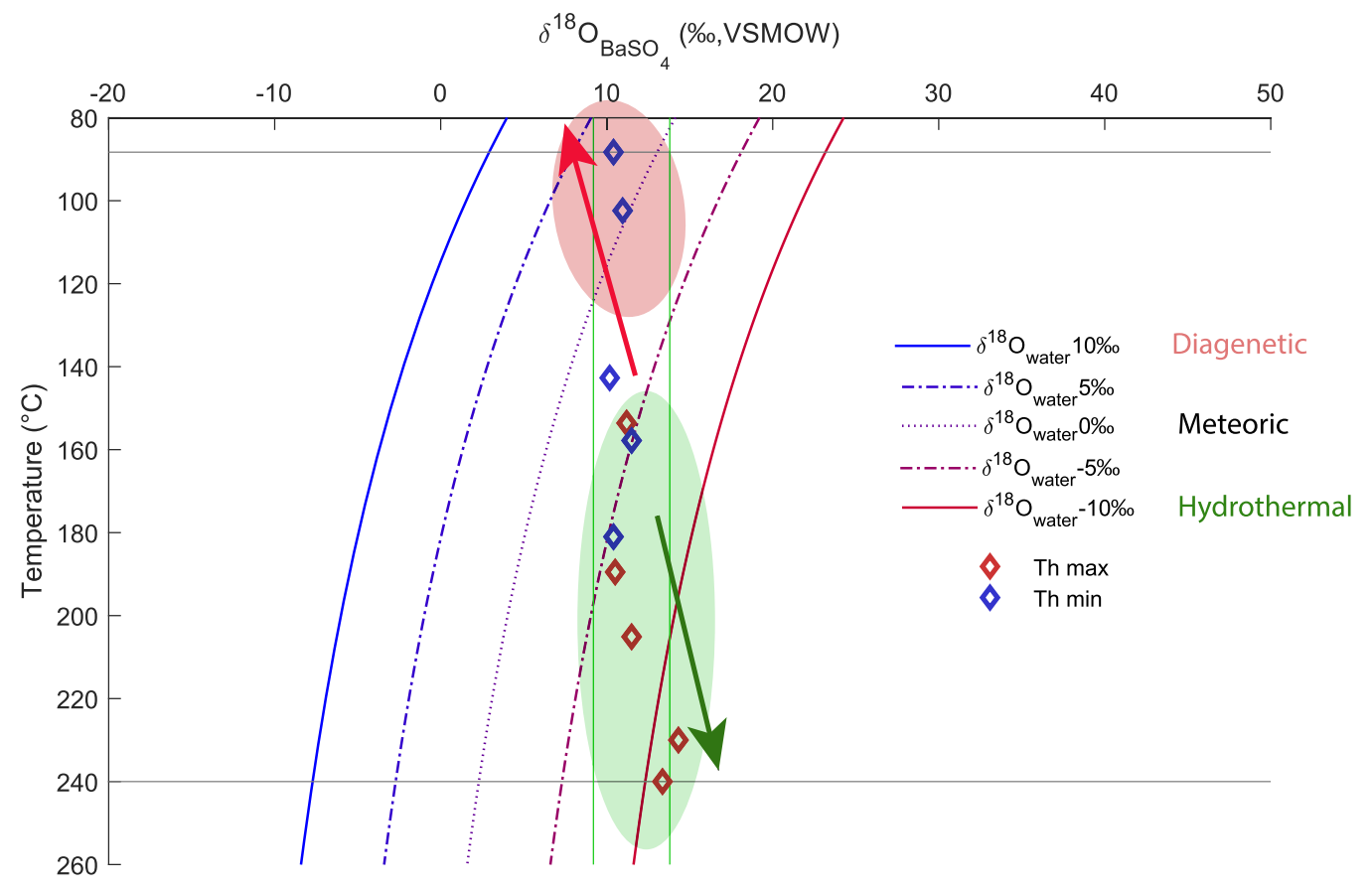

Fig. 14. Isotopic oxygen ratio of barite versus equilibrium temperature, for several determined isotopic compositions of the fluid, calculated after Kusakabe and Robinson (1977). Diamonds represent the samples for which both FI and barite isotope ratio are available. Red and green ellipses indicate the domain of fluid inclusions families identified in this study.

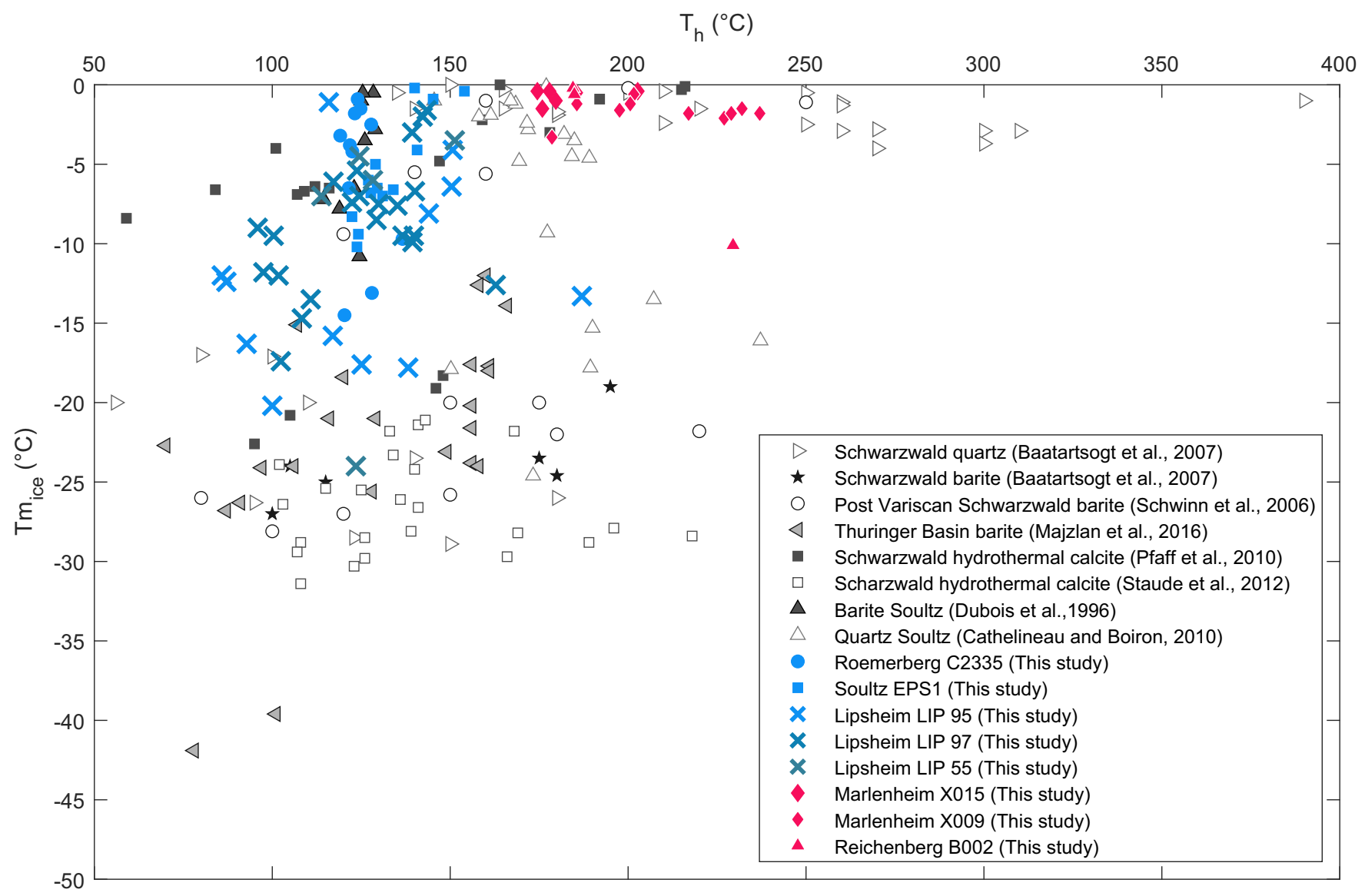

Fig. 15. Fluid inclusion data, compared with previous studies on vein mineralisations in the URG and neighbouring areas, e.g. for Schwarzwald quartz (Baatartsogt et al., 2007), for Schwarzwald barite (Schwinn et al., 2006; Baatartsogt et al., 2007) for Schwarzwald calcite (Pfaff et al., 2010; Staude et al., 2012), for Soultz barite (Dubois et al., 1996), for Soultz quartz (Cathelineau and Boiron, 2010), and for Thuringer Basin barite (Majzlan et al., 2016). 
probably have $\delta^{18} \mathrm{O}_{\text {fluid }}$ ranging from -10 to $-5 \%$. These $\delta^{18} \mathrm{O}_{\text {fluid }}$ values are typical of hot, hydrothermal fluids;

2 higher salinity fluids, with colder $\mathrm{T}_{\mathrm{h}}$ (from 80 to $140{ }^{\circ} \mathrm{C}$ ), and $\delta^{18} \mathrm{O}_{\text {barite }}$ from 9 to $13 \%$.

The deduced $\delta^{18} \mathrm{O}_{\text {fluid }}$ is ranging from -5 to $+3 \%$, which is typical for a fluid mixture composed by a) sedimentary brines usually having $\delta^{18} \mathrm{O}_{\text {fluid }}$ varying from 0 to $+2 \%$, and $b$ ) meteoric derived fluids with $\delta{ }^{18} \mathrm{O}_{\text {fluid }}$ below $-5 \%$.

The first group of hot fluids, with low salinity, is a hot geothermal fluid of meteoric origin. Such fluid presence suggests a pulse signature of meteoric downflow deep in the basement, followed by the flow of hot geothermal fluids reaching URG shoulders, signed by the high temperature (around $200^{\circ} \mathrm{C}$ ) and low salinity $\left(-4.6\right.$ to $\left.-1{ }^{\circ} \mathrm{C}\right)$ fluid inclusions. This type of fluids is also recorded within Lower Triassic sandstones in hydrothermal precipitations (quartz, fluorite, barite and siderite) on the eastern border of the URG (Brockamp and Clauer, 2005).

The second group of lowest temperatures, with variable salinity, is a mix between basin brines and meteoric waters.

\subsection{Fluid pathways and basin conceptual model}

Different fluid signatures depending on their structural locations were identified (Fig. 12). The different steps of the paragenesis are structured as follows:

1 A first phase composed by the pre-rifting diagenetic sequence: characterised by the development of siderite (Sd1) for which signal is recorded, as matrix cement, accompanied by feldspars and quartz overgrowths. This burial sequence recorded is similar in all locations.

2 A pre-rifting deformation phase characterised by deformation bands initiation. These deformation bands are observed within the deep-seated sandstones and concentrate diagenetic apatite crystals that record diagenetic fluids' print within deformation zones.

3 The first fracture cementations occurred, with quartz overgrowth precipitation from the formation waters enriched in $\mathrm{Si}$ by diagenetic illitisation.

4 Siderites $(\mathrm{Sd} 2)$ constitute the second fracture cementation phase and are located only within deep-seated reservoirs. These siderites precipitate from composite fluids, resulting from the mix of marine brines enriched in Fe and carbonate ions, and the more alkaline formation waters.

5 The barite precipitation records the third fracture cementation event. The geochemical signature of the barite is varying depending on the location of the samples. Within the basin, fluids are colder and could be more saline than for the shoulders. Sources are meteoric and basin brines for the deep-seated mineralisations, whereas sources are mainly meteoric and geothermal for the shoulders, with a small contribution of the basin brines. The presence of hydrocarbon-loaded secondary inclusions in some barite samples outlines that these barite mineralisations pre-date the reservoir oil charge, which occurred in Miocene (Böcker et al., 2016). This fluid flow event can be linked to the previously recorded Cenozoic hydrothermal pulses recorded within the Schwarzwald and Odenwald districts (named regional phase e) (Schwinn et al., 2006;
Baatartsogt et al., 2007; Pfaff et al., 2010; Walter et al., 2016, 2019).

6 Finally, the last carbonate $(\mathrm{Sd} 3)$ mineralisation phase seals barite cemented fractures for the deep seating basin samples (regional phase e).

$\mathrm{A} \mathrm{U} / \mathrm{Pb}$ dating of these mineralisation events would help to assess more precisely the window of fracture cementation depending on the location.

We propose the following model of fluid circulations in the URG, with an evolution of the fluid pathways versus time and space (Figs. 16 and 17).

The fluid pathway system needed to account for these different fluid circulations is also composite (Fig. 16). It is formed by the fault and fracture patterns and the sedimentary layers, especially the Triassic ones.

Schematically, following the basement structuration in blocks during the rift, deep, convective cells developed in the border fault zones with probably a branch flowing deeper towards the basement, through faults and fracture corridors. In the central part of the basin, fluid circulation is restricted to the bottom of the basin.

The preferential orientation of the cemented fractures, i.e. $\mathrm{N} 000-\mathrm{N} 010^{\circ} \mathrm{E}, \mathrm{N} 040^{\circ} \mathrm{E}, \mathrm{N} 140-\mathrm{N} 170^{\circ} \mathrm{E}$, and of fault systems $\left(\mathrm{N} 000^{\circ} \mathrm{E}\right.$ to $\left.\mathrm{N} 030^{\circ} \mathrm{E}\right)$ is compatible with their activation or reactivation in an $\mathrm{E}-\mathrm{W}$ extensional regime, mainly Oligocene in age, or/and in a left-shearing trans-tensive regime, Miocene in age (Schumacher, 2002; Lopes Cardozo and Behrmann, 2006).

The main fault damage zones and the fractures lattices are usable for meteoric water infiltration on the shoulders. Fluids are drained downward in the major border faults and toward the basin using the oblique faults network. The biggest faults, probably those with deepest roots, are usable for deep hot fluid to move upward. Secondary fault network develops horst and graben structures with several hundred meters of offset. (Boiron et al., 2011; Sanjuan et al., 2013; Dezayes and Lerouge, 2019). These faults affect the deep-seated reservoir and interact with the sedimentary aquifer. The convective cells regulating geothermal circulations is an hypothesis already proposed in previous studies (Baillieux et al., 2013; Guillou-Frottier et al., 2013; Freymark et al., 2017). According to the geometry of the structural network, the dimensions of the convective flow "loops" in the border cells, is controlled by faults segments, with a $10 \mathrm{~km}$ length order of magnitude. Fault zones oblique to the rift borders can also drain fluid toward the basin, which fits with flow patterns proposed by Guillou-Frottier et al. (2013), as the oblique faults and damage zones crosscut the impermeable fault cores of the border faults.

In the central part of the basin, the fluid circulation involves quartz, barite and siderite precipitation. Migration of sedimentary brine along the sedimentary cover-basement interface agrees with previous studies (Cathelineau and Boiron, 2010; Genter et al., 2010). These sedimentary brines mix with up-flowing hot low saline waters on horst structures, as in Soultz (Smith et al., 1998; Dubois et al., 2000; Guillou-Frottier et al., 2013) or Roemerberg (this study).

A hydraulic gradient must exist to allow fluid transfers. One possible way is through the hydrostatic gradient induced 

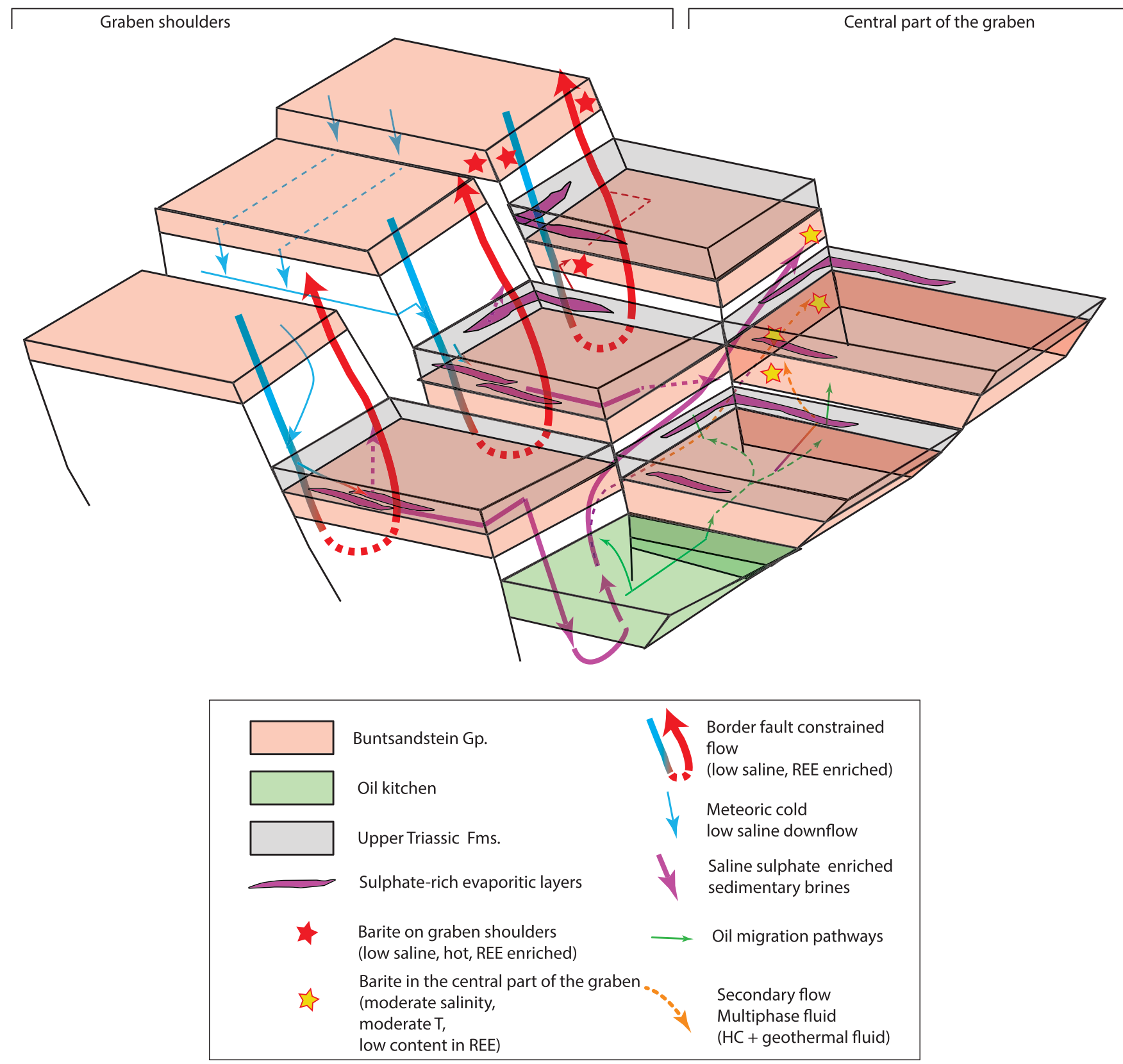

Fig. 16. Conceptual schematic model of fluid flow pathways within a block-structured rift margin.

by the topographic effect between the shoulders and the basin (Taillefer et al., 2018; Freymark et al., 2019). Such reasoning applies to the shoulders of the Rhine graben (Fig. 17). Before the rift opening, a regional scale uplift of the Rhenish Massif started in the Late Cretaceous and Paleocene. The Rhenish Massif acted since then, as a charging area for meteoric waters. The Vosges and the Black Forest massifs were uplifted during the rift opening (Eocene-Oligocene) and reactivated during the Miocene phase. Thus, these last two hydraulic charging areas were installed during the rift opening and reinforced during the Miocene tectonic reactivation phase. The recharge of the system by these topographic highs has been advocated regionally in the Schwarzwald, in the Hunsruck-Taunus and the Vosges Massifs (Fig. 17) (Cathelineau and Boiron, 2010;
Sanjuan et al., 2010; Staude et al., 2011; Loges et al., 2012; Walter et al., 2016).

In deep-seated reservoirs, fluid pressure within fault-systems would control migration by setting varying permeabilities and fracture network cementation. This effect of fluid pressure would add on the main driving force controlled by the main border fault systems parametrisation and topographic gradient. The current study reveals that an up-flow of hot geothermal fluids within the border faults led to barite mineralisations. This result emphasises the hypothesis that these border faults do not only act as a downflow drain but acted, at least in the past, as upward fluid pathways, and is complementary to previous studies conclusions (Sanjuan et al., 2016; Walter et al., 2018, 2019; Dezayes and Lerouge, 2019; Freymark et al., 2019). 

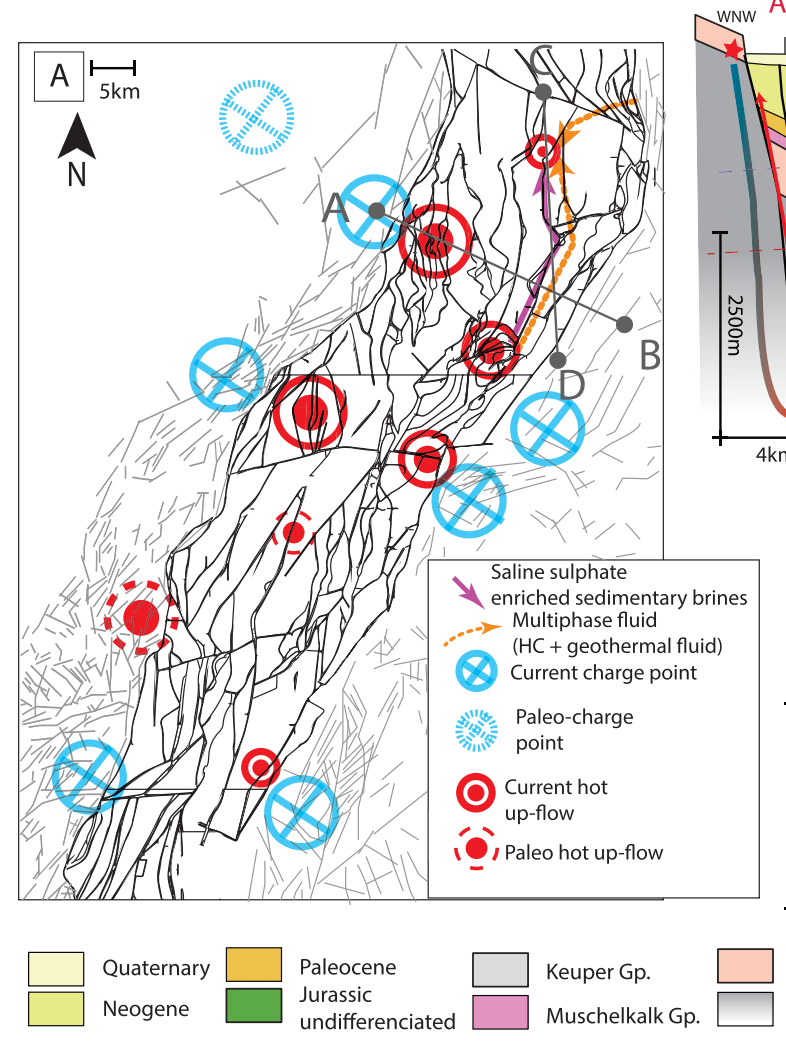
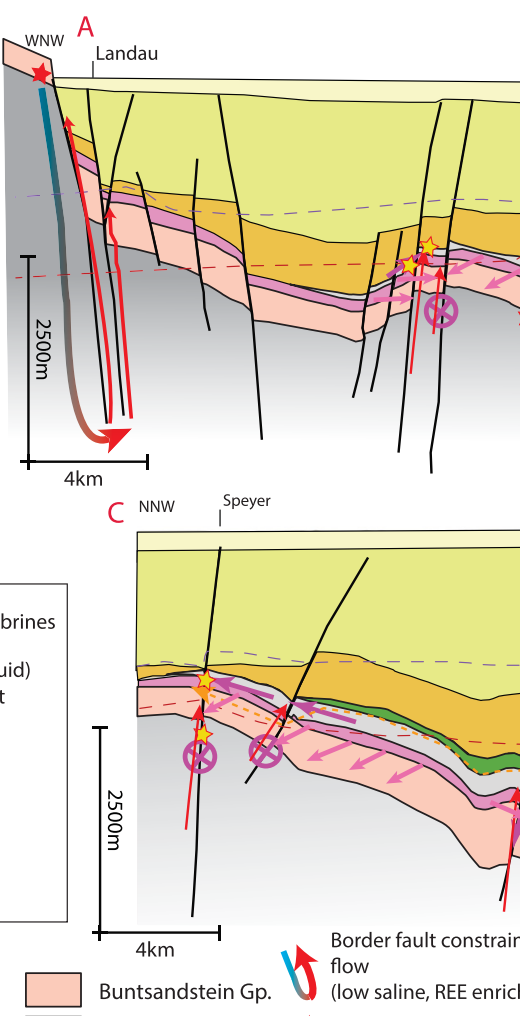

Basement
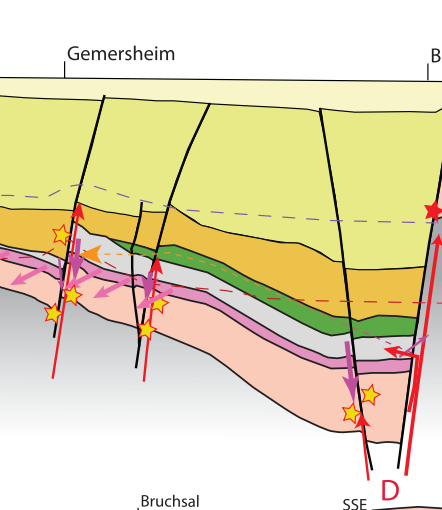

B ESE
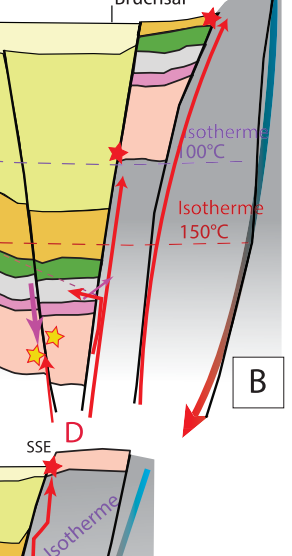

$\sqrt{8}$

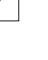

Fig. 17. Rift-scale fluid pathways. (A) Map of the basement fault network, with possible fluids migration through faults, and current and hypothetical paleo charge points. (B) WNW-ESE schematic geological cross-section, located on (A), with localisations of potential fluid pathways. (C) NNW-SSE schematic geological cross-section located on (A), showing potential fluid pathways through sedimentary layers, and fault systems.

\section{Conclusions}

The petrological and geochemical analysis provides tools to decipher the sources of fluid responsible for fracture mineralisation in the deep part of the URG and along its eastern and western shoulders.

The complex thermal history and subsequent flows of fluids within the Buntsandstein Gp. sandstone reservoirs are structured in distinct phases involving several fluids from different sources that were investigated in the Schwarzwald district (Danišík et al., 2010; Pfaff et al., 2010; Staude et al., 2011, 2012; Walter et al., 2016, 2018).

Regarding the condition of barite mineralisation, a common source for sulphate is the dissolution of Triassic evaporite. The precipitation regimes are varying following previous literature data. Shoulders show the warmest and least salty fluids, while fluids with variable salinity and relatively low temperature are in the central part of the basin. These basin fluids migrate through sedimentary drains in the deep part of the basin and permeable fault zones within the basement and potentially flow up on horst structures bordering structural blocks, such as Soultz or Landau. In the central buried reservoirs, these geothermal fluids mineralising barite are preceded and followed by the fracture network's siderite cementation. The interaction between diagenetic brines and geothermal fluids is mainly restricted to fractures oriented $\mathrm{N} 000-\mathrm{N} 010^{\circ} \mathrm{E}$ and $\mathrm{N} 150-170^{\circ} \mathrm{E}$.

These fluids pathways can only be active if the blocks architecture already existed. Given the age of the observed fault systems, the cementation of fracture network could start as soon as the Paleocene, and the structures located in the central parts of the basin, then probably appeared in the Oligocene-Miocene periods. The siderite and secondary apatite are mostly linked to diagenetic mineralisation of the open fractures. However, these fluid pathways and precipitation conditions are not fully understood within the deep central part of the basin and require further investigation.

Deep infiltrations of meteoric fluids explain graben shoulder mineralisations, topographically driven, and therefore the required presence of relief in the vicinity. This meteoric fluid circulation is restricted around major faults with a high throw, as they constitute the main drains, with a rise of hot, Ba-rich fluids, which leach out a portion of the sulphaterich formations on the buried blocks, forming the barite deposits, in fractures, at high temperature.

The influence of the basin fluids is crucial from the early diagenesis on, and continues throughout the history of the sandstones, with a matrix and fracture diagenesis whose prerift (Jurassic), syn-rift (Oligocene) and post-rift (Miocene) phases are marked by the role of meteoric and geothermal 
fluids as a vector of the material taken by dissolution in the Upper Triassic formations and mainly stored in the Triassic formations.

The up- and down-flows within border faults and the deep circulations can also still be active at present, as suggested by the presence of a positive thermal anomaly, which is related to deep geothermal fluid circulation in an area between Strasbourg in the South and Roemerberg (Speyer) in the North (Baillieux et al., 2013; Vidal and Genter, 2018). The presence of similar hot geothermal fluid pulses and structures along the northern edge of the URG (Loges et al., 2012) and the similar nature of current brines could suggest that such fluid flow pathways between the basement and sedimentary cover are still active. They should then be considered precisely in geothermal reservoir characterisation because these flow pathways are the targeted resources and their induced modifications on the fracture network's effective permeability.

\section{Supplementary Material}

The geochemical and structural data used to support this study's findings.

The Supplementary Material is available at http://www.bsgf.fr/ 10.1051/bsgf/2021027/olm.

Acknowledgements. We want to thank the geoscience team from ENGIE Deutschland GmbH (now Neptune Energy Germany) and their partner Palatina GeoCon to supply core material, scientific support, and rich debates. All the GeoRessources laboratory, Neptune Energy and ENGIE collaborators are thanked for numerous advices, settings supplies and help with measurements, the help and experience of the collaborators from the CRPG laboratory (Nancy). We would like to thank the ChronoEnvironnement laboratory in Besançon, for the supply of cold cathode facility, and discussions on diagenesis of fractured sandstones. We are grateful to the editor and the reviewers for their time and suggestions for improving the manuscript.

Conflicts of interest. The authors declare that there is no conflict of interest regarding the publication of this paper.

\section{Funding statement}

PhD grant from ENGIE, Neptune Energy and the Université de Lorraine supports this research and publication.

\section{Data availability}

The supplementary data file includes the geochemical and structural data used to support this study's findings.

\section{References}

Azmy K, Brand U, Sylvester P, Gleeson SA, Logan A, Bitner MA. 2011. Biogenic and abiogenic low-Mg calcite (bLMC and aLMC): Evaluation of seawater-REE composition, water masses and carbonate diagenesis. Chemical Geology 280: 180-190.

Baatartsogt B, Schwinn G, Wagner T, Taubald H, Beitter T, Markl G. 2007. Contrasting paleofluid systems in the continental basement:
A fluid inclusion and stable isotope study of hydrothermal vein mineralisation, Schwarzwald district, Germany. Geofluids 7: 123147.

Bächler D, Kohl T, Rybach L. 2003. Impact of graben-parallel faults on hydrothermal convection-Rhine Graben case study. Physics and Chemistry of the Earth 28: 431-441.

Baillieux P, Schill E, Edel J-B, Mauri G. 2013. Localization of temperature anomalies in the Upper Rhine Graben: Insights from geophysics and neotectonic activity. International Geology Review 55: 1744-1762.

Bau M, Dulski P. 1996. Distribution of yttrium and rare-earth elements in the Penge and Kuruman iron-formations, Transvaal Supergroup, South Africa. Precambrian Research 79: 37-55.

Bau M, Romer RL, Lüders V, Dulski P. 2003. Tracing element sources of hydrothermal mineral deposits: REE and $\mathrm{Y}$ distribution and $\mathrm{Sr}-$ $\mathrm{Nd}-\mathrm{Pb}$ isotopes in fluorite from MVT deposits in the Pennine Orefield, England. Mineralium Deposita 38: 992-1008.

Bense VF, Gleeson T, Loveless SE, Bour O, Scibek J. 2013. Fault zone hydrogeology. Earth-Science Reviews. Elsevier B.V. 127: 171-192.

Bertrand L, Jusseaume J, Géraud Y, Diraison M, Damy PC, Navelot $\mathrm{V}$, et al. 2018. Structural heritage, reactivation and distribution of fault and fracture network in a rifting context: Case study of the western shoulder of the Upper Rhine Graben. Journal of Structural Geology, Elsevier Ltd 108: 243-255.

Blaise T, Clauer N, Cathelineau M, Boiron M-CC, Techer I, Boulvais P. 2016. Reconstructing fluid-flow events in Lower-Triassic sandstones of the eastern Paris Basin by elemental tracing and isotopic dating of nanometric illite crystals. Geochimica et Cosmochimica Acta, Elsevier Ltd 176: 157-184.

Böcker J, Littke R, Forster A. 2016. An overview on source rocks and the petroleum system of the central Upper Rhine Graben. International Journal of Earth Sciences, Springer Berlin Heidelberg.

Boiron MC, Cathelineau M, Richard A. 2011. Fluid Flows and Metal Deposition near Basement/Cover Unconformity: Lessons and Analogies from $\mathrm{Pb}-\mathrm{Zn}-\mathrm{F}-\mathrm{Ba}$ Systems for the Understanding of Proterozoic U Deposits. Frontiers in Geofluids 10: 270-292.

Bons PD, Fusswinkel T, Gomez-Rivas E, Markl G, Wagner T, Walter B. 2014. Fluid mixing from below in unconformity-related hydrothermal ore deposits. Geology 42: 1035-1038.

Bons PD, Gomez-Rivas E. 2013. Gravitational fractionation of isotopes and dissolved components as a first-order process in crustal fluids. Economic Geology 108: 1195-1201.

Boschetti T. 2013. Oxygen isotope equilibrium in sulfate-water systems: A revision of geothermometric applications in lowenthalpy systems. Journal of Geochemical Exploration, Elsevier B. V. 124: $92-100$.

Boschetti T, Cortecci G, Toscani L, Iacumin P. 2011. Sulfur and oxygen isotope compositions of Upper Triassic sulfates from northern Apennines (Italy): Paleogeographic and hydrogeochemical implications. Geologica Acta 9: 129-147.

Bossennec C, Geraud Y, Moretti I, Mattioni L, Stemmelen D. 2018. Pore network properties of sandstones in a fault damage zone. Journal of Structural Geology, Pergamon 110: 24-44.

Bouch JE, Naden J, Shepherd TJ, McKervey JA, Young B, Benham AJ, et al. 2006. Direct evidence of fluid mixing in the formation of stratabound $\mathrm{Pb}-\mathrm{Zn}-\mathrm{Ba}-\mathrm{F}$ mineralisation in the Alston Block, North Pennine Orefield (England). Mineralium Deposita 41: 821835.

Bourgeois O, Ford M, Diraison M, Le Carlier de Veslud C, Gerbault M, Pik R, et al. 2007. Separation of rifting and lithospheric folding signatures in the NW-Alpine foreland. International Journal of Earth Sciences 96: 1003-1031. 
Bourquin S, Peron S, Durand M. 2006. Lower Triassic sequence stratigraphy of the western part of the Germanic Basin (west of Black Forest): Fluvial system evolution through time and space. Sedimentary Geology 186: 187-211.

Bourquin S, Guillocheau F, Péron S. 2009. Braided rivers within an arid alluvial plain (example from the lower triassic, western german basin): Recognition criteria and expression of stratigraphic cycles. Sedimentology 56: 2235-2264.

Brockamp O, Clauer N. 2005. A km-scale illite alteration zone in sedimentary wall rocks adjacent to a hydrothermal fluorite vein deposit. Clay Minerals 40: 245-260.

Brockamp O, Schlegel A, Clauer N. 2011. Mesozoic hydrothermal impact on Rotliegende and Bunter immature sandstones of the High Rhine trough and its adjacent eastern area (southern Black Forest, Germany. Sedimentary Geology, Elsevier B.V. 234: 76-88.

Burisch M, Gerdes A, Walter BF, Neumann U, Fettel M, Markl G. 2017a. Methane and the origin of five-element veins: Mineralogy, age, fluid inclusion chemistry and ore forming processes in the Odenwald, SW Germany. Ore Geology Reviews, Elsevier B.V. 81: 42-61.

Burisch M, Walter BF, Gerdes A, Lanz M, Markl G. 2017b. Latestage anhydrite-gypsum-siderite-dolomite-calcite assemblages record the transition from a deep to a shallow hydrothermal system in the Schwarzwald mining district, SW Germany. Geochimica et Cosmochimica Acta, Elsevier Ltd 223: 259-278.

Caetano M, Prego R, Vale C, de Pablo H, Marmolejo-Rodríguez J. 2009. Record of diagenesis of rare earth elements and other metals in a transitional sedimentary environment. Marine Chemistry, Elsevier B.V. 116: 36-46.

Carpentier C, Brigaud B, Blaise T, Vincent B, Durlet C, Boulvais P, et al. 2014. Impact of basin burial and exhumation on Jurassic carbonates diagenesis on both sides of a thick clay barrier (Paris Basin, NE France. Marine and Petroleum Geology, Elsevier Ltd 53: 44-70.

Cathelineau M, Boiron M-C. 2010. Downward penetration and mixing of sedimentary brines and dilute hot waters at $5 \mathrm{~km}$ depth in the granite basement at Soultz-sous-Forêts (Rhine graben, France. Comptes Rendus Geoscience. Academie des sciences 342: 560565.

Cathelineau M, Fourcade S, Clauer N, Buschaert S, Rousset D, Boiron M-CC, et al. 2004. Dating multistage paleofluid percolations: A K-Ar and ${ }^{18} \mathrm{O} /{ }^{16} \mathrm{O}$ study of fracture illites from altered Hercynian plutonites at the basement/cover interface (Poitou High, France. Geochimica et Cosmochimica Acta 68: 2529-2542.

Cathelineau M, Boiron M-CC, Fourcade S, Ruffet G, Clauer N, Belcourt O, et al. 2012. A major Late Jurassic fluid event at the basin/basement unconformity in western France: ${ }^{40} \mathrm{Ar} /{ }^{39} \mathrm{Ar}$ and $\mathrm{K}-$ Ar dating, fluid chemistry, and related geodynamic context. Chemical Geology, Elsevier B.V. 322-323: 99-120.

Clauer N, Liewig N, Ledesert B, Zwingmann H. 2008. Thermal history of Triassic sandstones from the Vosges Mountains-Rhine Graben rifting area, NE France, based on $\mathrm{K}-\mathrm{Ar}$ illite dating. Clay Minerals 43: 363-379.

Cloetingh S, Ziegler PA, Beekman F, Andriessen PAM, Hardebol N, Dèzes P. 2005. Intraplate deformation and 3D rheological structure of the Rhine Rift System and adjacent areas of the northern Alpine foreland. International Journal of Earth Sciences 94: 758-778.

Cloetingh S, Cornu T, Ziegler PA, Beekman F, Ustaszewski K, Schmid SM, et al. 2006. Neotectonics and intraplate continental topography of the northern Alpine Foreland. Earth-Science Reviews 74: 127-196.
Cloetingh S, van Wees JD, Ziegler PA, Lenkey L, Beekman F, Tesauro M, et al. 2010. Lithosphere tectonics and thermo-mechanical properties: An integrated modelling approach for Enhanced Geothermal Systems exploration in Europe. Earth-Science Reviews, Elsevier B.V. 102: 159-206.

Danišík M, Pfaff K, Evans NJ, Manoloukos C, Staude S, McDonald BJ, et al. 2010. Tectonothermal history of the Schwarzwald Ore District (Germany): An apatite triple dating approach. Chemical Geology 278: 58-69.

Derer CE, Schumacher ME, Schäfer A. 2005. The northern Upper Rhine Graben: basin geometry and early syn-rift tectonosedimentary evolution. International Journal of Earth Sciences 94: 640-656.

Dezayes C, Lerouge C. 2019. Reconstructing Paleofluid Circulation at the Hercynian Basement/Mesozoic Sedimentary Cover Interface in the Upper Rhine Graben. Geofluids 2019: 1-30.

Dezayes C, Lerouge C, Sanjuan B, Ramboz C, Brach M. 2015. Toward a better understanding of the fluid circulation in the Rhine Graben for a better geothermal exploration of the deep basins. In: Proceedings World Geothermal Congress 2015, pp. 19-25.

Dolníček Z, Lehotský T, Slobodník M, Hejtmánková E, Grígelová A, Zapletal J. 2014. Mineral-forming and diagenetic processes related to tertiary hydrocarbon seepage at the bohemian massif/outer western carpathians interface: Evidence from the hrab??vka quarry, moravia, czech republic. Marine and Petroleum Geology 52: 77-92.

Dubois M, Ledésert B, Potdevin J-L, Vançon S. 2000. Détermination des conditions de précipitation des carbonates dans une zone d'altération du granite de Soultz (soubassement du fossé Rhénan, France) : l'enregistrement des inclusions fluides. Comptes Rendus de l'Académie des Sciences-Series IIA-Earth and Planetary Science 331: 303-309.

Dubois M, Ougougdal MA, Meere P, Royer JJ, Boiron MC, Cathelineau M. 1996. Temperature of paleo- to modern self-sealing within a continental rift basin: The fluid inclusion data (Soultzsous-Forets, Rhine graben, France). European Journal Of Mineralogy 8: 1065-1080.

Edel J-B, Schulmann K, Rotstein Y. 2007. The Variscan tectonic inheritance of the Upper Rhine Graben: evidence of reactivations in the Lias, Late Eocene-Oligocene up to the recent. International Journal of Earth Sciences 96: 305-325.

Eisbacher GH, Fielitz W. 2010. Karlsruhe und seine RegionNordschwarzwald, Kraichgau, Neckartal, südlicher Odenwald, Oberrhein-Graben, Pfälzerwald und westliche Schwäbische Alb. Stuttgart, Germany: Schweizerbart Science Publishers.

Freymark J, Sippel J, Scheck-Wenderoth M, Bär K, Stiller M, Fritsche JG, et al. 2017. The deep thermal field of the Upper Rhine Graben. Tectonophysics, Elsevier B.V. 694: 114-129.

Freymark J, Bott J, Cacace M, Ziegler M, Scheck-wenderoth M. 2019. Influence of the main border faults on the 3D hydraulic field of the Central Upper Rhine Graben. Geofluids 2019: 19-22.

Genter A, Evans K, Cuenot N, Fritsch D, Sanjuan B. 2010. Contribution of the exploration of deep crystalline fractured reservoir of Soultz to the knowledge of enhanced geothermal systems (EGS). Comptes Rendus-Geoscience. Academie des sciences 342: 502-516.

Gleeson SA, Wilkinson JJ, Stuart FM, Banks DA. 2001. The origin and evolution of base metal mineralising brines and hydrothermal fluids, South Cornwall, UK. Geochimica et Cosmochimica Acta 65: 2067-2079.

Göb S, Loges A, Nolde N, Bau M, Jacob DE, Markl G. 2013. Major and trace element compositions (including REE) of mineral, thermal, mine and surface waters in SW Germany and implications 
for water-rock interaction. Applied Geochemistry, Elsevier Ltd 33: $127-152$.

Griffiths L, Heap MJ, Wang F, Daval D, Gilg HA, Baud P, et al. 2016. Geothermal implications for fracture-filling hydrothermal precipitation. Geothermics. CNR-Istituto di Geoscienze e Georisorse 64: 235-245.

Guillocheau F, Robin C, Allemand P, Bourquin S, Brault N, Dromart $\mathrm{G}$, et al. 2000. Meso-Cenozoic geodynamic evolution of the Paris Basin: 3D stratigraphic constraints. Geodinamica Acta 13: 189245.

Guillou-Frottier L, Carre C, Bourgine B, Bouchot V, Genter A. 2013. Structure of hydrothermal convection in the Upper Rhine Graben as inferred from corrected temperature data and basin-scale numerical models. Journal of Volcanology and Geothermal Research 256: 29-49.

Haffen S. 2012. Caractéristiques géothermiques du réservoir gréseux du Buntsandstein d'Alsace. University of Strasbourg.

Haley BA, Klinkhammer GP, McManus J. 2004. Rare earth elements in pore waters of marine sediments. Geochimica et Cosmochimica Acta 68: 1265-1279.

Harlé P, Kushnir Alexandra RL, Aichholzer C, Heap Michael J, Hehn $\mathrm{R}$, Maurer V, et al. 2019. Heat flow density estimates in the Upper Rhine Graben using laboratory measurements of thermal conductivity on sedimentary rocks. Geothermal Energy. Springer Berlin Heidelberg.

Illies JH. 1972. The Rhine Graben rift system-Plate tectonics and transform faulting. Geophysical Surveys 1: 27-60.

Joosu L, Lepland A, Kreitsmann T, Üpraus K, Roberts NMW, Paiste P, et al. 2016. Petrography and the REE-composition of apatite in the Paleoproterozoic Pilgujärvi Sedimentary Formation, Pechenga Greenstone Belt, Russia. Geochimica et Cosmochimica Acta 186: 135-153.

Kristensen TB, Rotevatn A, Peacock DCP, Henstra GA, Midtkandal I, Grundvåg SA. 2016. Structure and flow properties of syn-rift border faults: The interplay between fault damage and fault-related chemical alteration (Dombjerg Fault, Wollaston Forland, NE Greenland. Journal of Structural Geology, Elsevier Ltd 92: 99-115.

Kusakabe M, Robinson BW. 1977. Oxygen and sulfur isotope equilibria in the $\mathrm{BaSO}_{4} \mathrm{HSO}_{4} \backslash \mathrm{n}-\mathrm{H}_{2} \mathrm{O}$ system from 110 to $350{ }^{\circ} \mathrm{C}$ and applications. Geochimica et Cosmochimica Acta 41: 10331040.

Kushnir ARL, Heap MJ, Baud P, Gilg HA, Reuschlé T, Lerouge C, et al. 2018. Characterising the physical properties of rocks from the Paleozoic to Permo-Triassic transition in the Upper Rhine Graben. Geothermal Energy, Springer Berlin Heidelberg, 6 p.

Lampe C, Person M, Nöth S, Ricken W. 2001. Episodic fluid flow within continental rift basins: Some insights from field data and mathematical models of the Rhinegraben. Geofluids 1: 42-52.

Loges A, Wagner T, Kirnbauer T, Göb S, Bau M, Berner Z, et al. 2012. Source and origin of active and fossil thermal spring systems, northern Upper Rhine Graben, Germany. Applied Geochemistry, Elsevier Ltd 27: 1153-1169.

Lopes Cardozo GGO, Behrmann JH. 2006. Kinematic analysis of the Upper Rhine Graben boundary fault system. Journal of Structural Geology 28: 1028-1039.

Lucazeau F, Vasseur G. 1989. Heat flow density data from France and surrounding margins. Tectonophysics 164: 251-258.

Lutz H, Kaulfuss U, Wappler T, Löhnertz W, Wilde V, Mertz DF, et al. 2010. Eckfeld Maar: Window into an Eocene Terrestrial Habitat in Central Europe. Acta Geologica Sinica-English Edition 84: 9841009.

Lutz H, Lorenz V, Engel T, Häfner F, Haneke J. 2013. Paleogene phreatomagmatic volcanism on the western main fault of the northern Upper Rhine Graben (Kisselwörth diatreme and Nierstein-Astheim Volcanic System, Germany. Bulletin of Volcanology 75: 1-11.

Majzlan J, Brey-Funke M, Malz A, Donndorf S, Milovský R. 2016. Fluid evolution and mineralogy of $\mathrm{Mn}-\mathrm{Fe}$-barite-fluorite mineralisations at the contact of the Thuringian Basin, Thüringer Wald and Thüringer Schiefergebirge in Germany. Geologica Carpathica 67: 3-20.

McConnell D. 1973. Apatite-Its crystal chemistry, mineralogy, utilization, and geologic and biologic occurrences. Applied Mineralogy, 48-80.

McKinley JM, Atkinson PM, Lloyd CD, Ruffell AH, Worden RH. 2011. How porosity and permeability vary spatially with grain size, sorting, cement volume, and mineral dissolution in fluvial Triassic sandstones: the value of geostatistics and local regression. Journal of Sedimentary Research 81: 844-858.

Meixner J, Grimmer JC, Becker A, Schill E, Kohl T. 2018. Comparison of different digital elevation models and satellite imagery for lineament analysis: Implications for identification and spatial arrangement of fault zones in crystalline basement rocks of the southern Black Forest (Germany. Journal of Structural Geology, Elsevier Ltd 108: 256-268.

Olivarius M, Weibel R, Hjuler ML, Kristensen L, Mathiesen A, Nielsen LH, et al. 2015. Diagenetic effects on porosity-Permeability relationships in red beds of the Lower Triassic Bunter Sandstone Formation in the North German Basin. Sedimentary Geology, Elsevier B.V. 321: 139-153.

Paradis S, Hannigan P, Dewing K. 2007. Mineral Deposits of Canada Mississippi Valley-type Lead-Zinc deposits (MVT).

Person M, Garven G. 1992. Hydrologic constraints on petroleum generation within continental rift basins: theory and application to the Rhine Graben. American Association of Petroleum Geologists Bulletin 76: 468-488.

Pfaff K, Hildebrandt LH, Leach DL, Jacob DE, Markl G. 2010. Formation of the Wiesloch Mississippi Valley-type $\mathrm{Zn}-\mathrm{Pb}-\mathrm{Ag}$ deposit in the extensional setting of the Upper Rhinegraben, SW Germany. Mineralium Deposita 45: 647-666.

Pourmand A, Dauphas N, Ireland TJ. 2012. A novel extraction chromatography and MC-ICP-MS technique for rapid analysis of REE, Sc and Y: Revising CI-chondrite and Post-Archean Australian Shale (PAAS) abundances. Chemical Geology, Elsevier B.V. 291: 38-54.

Pribnow D, Schellschmidt R. 2000. Thermal tracking of upper crustal fluid flow in the Rhine Graben. Geophysical Research Letters 27: 1957-1960.

Ranalli G, Rybach L. 2005. Heat flow, heat transfer and lithosphere rheology in geothermal areas: Features and examples. Journal of Volcanology and Geothermal Research 148: 3-19.

Reicherter K, Froitzheim N, Jarosiński M, Badura J, Franzke H-J, Hansen M, et al. 2008. Alpine tectonics north of the Alps. Geology of Central Europe 2: 1233-1285.

Rotstein Y, Schaming M, Rousse S. 2005. Tertiary tectonics of the Dannemarie basin, upper Rhine graben, and regional implications. International Journal of Earth Sciences 94: 669-679.

Roussé S. 2006. Architecture et dynamique des séries marines et continentales de l'Oligocène Moyen et Supérieur du Sud du Fossé Rhénan: évolution des milieux de dépôt en contexte de rift en marge de l'avant-pays alpin. PhD Thesis, University Louis Pasteur of Strasbourg.

Sanjuan B, Millot R, Dezayes C, Brach M. 2010. Main characteristics of the deep geothermal brine $(5 \mathrm{~km})$ at Soultz-sous-Forêts (France) determined using geochemical and tracer test data. Comptes Rendus Geoscience. Academie des sciences 342: 546-559. 
Sanjuan B, Millot R, Dezayes C, Brach M, Sanjuan B, Millot R, et al. 2013. Fluid origin and circulation in the heat exchanger of ETS ( France) estimated using geochemical and tracer test data. To cite this version.

Sanjuan B, Millot R, Innocent C, Dezayes C, Scheiber J, Brach M. 2016. Major geochemical characteristics of geothermal brines from the Upper Rhine Graben granitic basement with constraints on temperature and circulation. Chemical Geology, Elsevier B.V. 428: $27-47$.

Schleicher AM, Warr LN, Kober B, Laverret E, Clauer N. 2006 a. Episodic mineralisation of hydrothermal illite in the Soultz-sousForêts granite (Upper Rhine Graben, France). Contributions to Mineralogy and Petrology 152: 349-364.

Schleicher AM, Warr LN, Van der Pluijm BA. 2006b. Fluid focusing and back-reactions in the uplifted shoulder of the Rhine rift system: A clay mineral study along the Schauenburg Fault zone (Heidelberg, Germany. International Journal of Earth Sciences 95: 19-33.

Schumacher ME. 2002. Upper Rhine Graben: Role of preexisting structures during rift evolution. Tectonics 21 .

Schwinn G, Wagner T, Baatartsogt B, Markl G. 2006. Quantification of mixing processes in ore-forming hydrothermal systems by combination of stable isotope and fluid inclusion analyses. Geochimica et Cosmochimica Acta 70: 965-982.

Shields G, Stille P. 2001. Diagenetic constraints on the use of cerium anomalies as palaeoseawater redox proxies: An isotopic and REE study of Cambrian phosphorites. Chemical Geology 175: 29-48.

Sissingh W. 1998. Comparative tertiary stratigraphy of the Rhine Graben, Bresse Graben and Molasse Basin: Correlation of Alpine foreland events. Tectonophysics 300: 249-284.

Sizun J-P. 1995. Modifications des structures de porosité de grès lors de transformations pétrographiques dans la diagenèse et l'hydrothermalisme: application au Trias de la marge ardéchoise et du fossé rhénan. Université Louis Pasteur de Strasbourg.

Skrzypek E. 2011. Contribution structurale, pétrologique et géochronologique à la tectonique intracontinentale de la chaîne hercynienne d'Europe (Sudètes, Vosges). Unpublished PhD. Thesis, Université de Strasbourg, $380 \mathrm{p}$.

Smith MP, Savary V, Yardley BWD, Valley JW, Royer JJ, Dubois M. 1998. The evolution of the deep flow regime at Soultz-sous-Forêts, Rhine Graben, eastern France: Evidence from a composite quartz vein. J. Geophys. Res. 103: 27223-27237.

Soyk D. 2015. Diagenesis and reservoir quality of the Lower and Middle Buntsandstein (Lower Triassic), SW Germany. RuprechtKarls-Universität Heidelberg.

Staude S, Bons PD, Markl G. 2009. Hydrothermal vein formation by extension-driven dewatering of the middle crust: An example from SW Germany. Earth and Planetary Science Letters, Elsevier B.V. 286: 387-395.

Staude S, Göb S, Pfaff K, Ströbele F, Premo WR, Markl G. 2011. Deciphering fluid sources of hydrothermal systems: A combined Sr- and S-isotope study on barite (Schwarzwald, SW Germany. Chemical Geology, Elsevier B.V. 286: 1-20.
Staude S, Mordhorst T, Nau S, Pfaff K, Brügmann G, Jacob DE, et al. 2012. Hydrothermal carbonates of the Schwarzwald ore district, southwestern Germany: Carbon source and conditions of formation using delta ${ }^{18} \mathrm{O}$, delta ${ }^{13} \mathrm{C},{ }^{87} \mathrm{Sr} /{ }^{86} \mathrm{Sr}$, and fluid inclusions. The Canadian Mineralogist 50: 1401-1434.

Stober I, Bucher K. 2004. Fluid sinks within the earth's crust. Geofluids 4: 143-151.

Taillefer A, Guillou-Frottier L, Soliva R, Magri F, Lopez S, Courrioux G, et al. 2018. Topographic and Faults Control of Hydrothermal Circulation Along Dormant Faults in an Orogen. Geochemistry, Geophysics, Geosystems 19: 4972-4995.

Tostevin R, Shields GA, Tarbuck GM, He T, Clarkson MO, Wood RA. 2016. Effective use of cerium anomalies as a redox proxy in carbonate-dominated marine settings. Chemical Geology, The Authors 438: 146-162.

Vidal J. 2017. Altérations hydrothermales associées aux zones de fractures à l'interfae de la couverture sédimentaire et du socle cristallin dans le Fossé rhénan supérieur. Application aux forages géothermiques de Rittershoffen (Alsace, France, Université de Strasbourg).

Vidal J, Genter A. 2018. Overview of naturally permeable fractured reservoirs in the central and southern Upper Rhine Graben: Insights from geothermal wells. Geothermics, Pergamon 74: 57-73.

Vidal J, Genter A, Schmittbuhl J. 2015. How do permeable fractures in the Triassic sediments of Northern Alsace characterise the top of hydrothermal convective cells? Evidence from Soultz geothermal boreholes (France). Geothermal Energy 3: 8.

Walter BF, Burisch M, Markl G. 2016. Long-term chemical evolution and modification of continental basement brines - A field study from the Schwarzwald, SW Germany. Geofluids 16: 604-623.

Walter BF, Burisch M, Marks MAW, Markl G. 2017. Major element compositions of fluid inclusions from hydrothermal vein-type deposits record eroded sedimentary units in the Schwarzwald district, SW Germany. Mineralium Deposita 52: 1191-1204.

Walter BF, Burisch M, Fusswinkel T, Marks MAW, Steele-MacInnis M, Wälle M, et al. 2018. Multi-reservoir fluid mixing processes in rift-related hydrothermal veins, Schwarzwald, SW-Germany. Journal of Geochemical Exploration, Elsevier 186: 158-186.

Walter BF, Kortenbruck P, Scharrer M, Zeitvogel C, Wälle M, MertzKraus R, et al. 2019. Chemical evolution of ore-forming brines - Basement leaching, metal provenance, and the redox link between barren and ore-bearing hydrothermal veins. A case study from the Schwarzwald mining district in SW-Germany. Chemical Geology, Elsevier B.V. 506: 126-148.

Wilkinson JJ. 2003. On diagenesis, dolomitisation and mineralisation in the Irish $\mathrm{Zn}-\mathrm{Pb}$ orefield. Mineralium Deposita 38: 968-983.

Ziegler PA. 1992. European Cenozoic rift system. Tectonophysics 208: 91-111.

Ziegler PA. 2005. Europe | Permian to recent evolution. Encyclopedia of Geology, 102-105.

Ziegler PA, Schumacher ME, Dezes P, Van Wees J-D, Cloetingh S. 2004. Post-Variscan evolution of the lithosphere in the Rhine Graben area: Constraints from subsidence modelling. Geological Society, London, Special Publications 223: 289-317.

Cite this article as: Bossennec C, Géraud Y, Böcker J, Klug B, Mattioni L, Bertrand L, Moretti I. 2021. Characterisation of fluid flow conditions and paths in the Buntsandstein Gp. sandstones reservoirs, Upper Rhine Graben, BSGF - Earth Sciences Bulletin 192: 35. 